THE MYTH OF MASTER PLANNING: MORE THAN URBAN DESIGN:

A COMPARATIVE ANALYSIS OF THE MASTER-PLANNED AFFORDABLE HOUSING DEVELOPMENTS STUYVESANT TOWN AND REGENT PARK

\author{
by \\ Tneshia Pages \\ B.A. (Honours), University of Toronto, 2014 \\ A Major Research Paper \\ presented to Ryerson University \\ in partial fulfillment of the requirements for the degree of \\ Master of Planning \\ in \\ Urban Development
}

Toronto, Ontario, Canada, 2016

(C)Tneshia Pages, 2016 


\section{AUTHOR'S DECLARATION FOR ELECTRONIC SUBMISSION OF AMRP}

I hereby declare that I am the sole author of this MRP. This is a true copy of the MRP, including any required final revisions.

I authorize Ryerson University to lend this MRP to other institutions or individuals for the purpose of scholarly research.

I further authorize Ryerson University to reproduce this MRP by photocopying or by other means, in total or in part, at the request of other institutions or individuals for the purpose of scholarly research.

I understand that my MRP may be made electronically available to the public. 


\title{
THE MYTH OF MASTER PLANNING: MORE THAN URBAN DESIGN: A COMPARATIVE ANALYSIS OF THE MASTER-PLANNED AFFORDABLE HOUSING DEVELOPMENTS STUYVESANT TOWN AND REGENT PARK
}

\author{
(C)Tneshia Pages, 2016 \\ Master of Planning \\ in \\ Urban Development \\ Ryerson University
}

\begin{abstract}
This paper explores the role of urban planning policy, urban housing policy, and urban design on master planning. Though master planning as a concept has historically been tied to urban design, this paper argues that this notion is fundamentally flawed, and that urban planning policy and housing policy play an equally important role. This topic is explored through a case study analysis of Stuyvesant Town and Regent Park, master-planned affordable housing projects in New York City and Toronto, Ontario. With a focus on process, policy, and design, this paper will discuss how interpretations of master planning in New York and Toronto influenced the development of both housing projects. A comparative analysis of both projects highlights the multi-faceted nature of master planning, and demonstrate the importance of urban planning policy, housing policy, and urban design ideologies to master planning.
\end{abstract}

Key words: "master planning"; "policy"; "urban design"; "affordable housing" 


\section{ACKNOWLEDGEMENTS}

I would like to thank my supervisor Dr. Jaclene Begley for the inspiration for this paper. Thank you for introducing me to Stuy Town and for believing in my idea. Your guidance has resulted in a paper that I am truly proud of, and reflects my unique perspective as a budding planner.

Thank you to Dr. Steven Webber for contributing to this paper as my second reader.

Thank you to the faculty at the School of Urban and Regional Planning at Ryerson, from whom I was motivated to challenge the status quo, and to be a planner who jumps boldly towards change.

Thank you to my friends at SURP, whose passion, creativity, and varying worldly views have helped to shape my understanding of the world, and have pushed me to be a more thoughtful and engaged human being and citizen. Thank you for motivating me, lamenting with me, and keeping me a'float!

\section{DEDICATION}

To Mima

Thank you for believing in me to the ultimate end, and for seeing the potential in me when I cannot. Your continuous love, guidance, work ethic, and strength have made me who I am today, for which I will be forever grateful.

\section{To Matthew}

Thank you for trading in your engineering hard hat for a T-square and planning law over the last five years. Thank you for your motivation and love, and for reminding me of the world outside of academia. 


\section{TABLE OF CONTENTS}

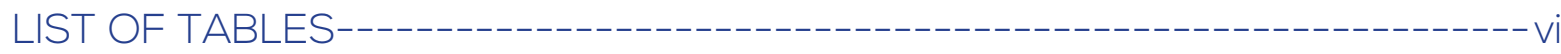

LIST OF FIGURES--

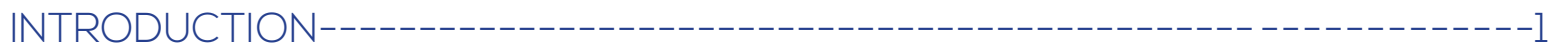

Paper Structure 1

Data Collection 1

MASTER PLANNING THE URBAN ENVIRONMENT--------------------------- 2

Master Planning: Historical Interpretations 2

The Master Plan: A Function of Design Alone? 4

NEW YORK CITY------------------------------------------------- 6

The History of Town Planning in New York City \& the United States 6

The History of Slum Clearance Ideology in New York City \& The United States 6

Stuyvesant Town: Process, Policy, \& Urban Design 7

TORONTO----------------------------------------------------------11

The History of Town Planning in Toronto \& Canada 11

The History of Slum Clearance Ideology in Toronto \& Canada 11

Regent Park: Process, Policy, \& Urban Design 13

MASTER PLAN ANALYSIS: PROCESS, POLICY, \& URBAN DESIGN-------------16

$\begin{array}{ll}\text { Process } & 16\end{array}$

$\begin{array}{ll}\text { Policy } & 18\end{array}$

$\begin{array}{ll}\text { Urban Design } & 19\end{array}$

COMPARING THE LEGACIES OF STUYVESANT TOWN AND REGENT PARK----26

Policy Legacy 26

Urban Design Legacy 26

The 'Myth' of Master Planning: More than Urban Design 27

CONCLUSION: THE COMPLEX NATURE OF MASTER PLANNING--------------29

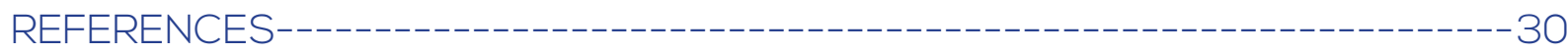




\section{LIST OF TABLES}

Table 1: Development Processes for Stuyvesant Town and Regent Park

Table 2: Socio-Economic Characteristics of Stuyvesant Town and Regent Park

Table 3: Policies Influencing the Development of Stuyvesant Town and Regent Park

Table 4: Urban Design of Stuyvesant Town and Regent Park

\section{LIST OF FIGURES}

Figure 1: Key Map of Stuyvesant Town, New York City

Figure 2: Aerial View of Stuyvesant Town, looking from East Fourteenth Street and Avenue C Figure 3: Fountain at Stuyvesant Oval

Figure 4: Wall Along East Fourteenth Street

Figure 5: Key Map of Regent Park, Toronto

Figure 6: Aerial View of Regent Park North and South, Looking East, 1980-1988

Figure 7: Stuyvesant Town Master Plan, New York City

Figure 8: Regent Park Master Plan, Toronto

Figure 9: Lynchian Analysis of Stuyvesant Town

Figure 10: Lynchian Analysis of Regent Park 


\section{INTRODUCTION}

This paper will argue that master planning is a function of both urban design and urban planning policy. Though master planning as a concept has historically been tied to urban design, this paper argues that this notion is fundamentally flawed, and that urban planning policy and housing policy play an equally important role. This paper's central research question is: what is the role of urban planning policy, urban housing policy, and urban design on master planning? This will be explored through a comparative case study analysis of master-planned affordable housing developments within North America: Stuyvesant Town in New York City, and Regent Park in Toronto, Ontario. Stuyvesant Town and Regent Park were both a response to the post-war affordable housing shortages and residential slums in their respective cities, which were developed during a similar time period, and designed with comparable urban design principles. This paper is a response to the blanket opinion that the urban design of Regent Park was solely responsible for its failure as a master-planned housing development. Regent Park is currently undergoing redevelopment due to its supposed design flaws, yet Stuyvesant Town has not experienced the same level of criticism on its urban design, and still exists as a housing development for middle-income New Yorkers. This paper will investigate the role of urban planning policy, urban housing policy, and urban design on the outcomes of both affordable housing projects, and use these conclusions to comment on the relationship of urban design and policy to master planning. This paper aims to contribute towards limited existing research on master planning, in the context of both urban design and urban planning.

\section{Paper Structure}

The paper will open by discussing historical definitions and interpretations of master planning, and its relationship to urban design. It will then provide background information for each case study, giving a brief history of relevant town planning and slum clearance ideologies. Each case study section will discuss the process used to realize their development, the policy influencing their creation, and the urban design ideologies that informed their master plan design. Following this section, a comparison of the process, policy, and urban design of Stuyvesant Town and Regent Park will be undertaken. Evidence from this analysis will be used to inform concluding thoughts on the role of urban design, urban planning policy, and housing policy on master planning.

\section{Data Collection}

This research aims to be exploratory in nature through a focus on qualitative data. Research was undertaken through a literature review of master planning, town planning, urban planning policy, and housing policy. Research was gathered from municipal archives, academic literature, and policy documents. Spatial data was collected from municipal open data and ESRI geographic information system (GIS) data repositories. 


\section{MASTER PLANNING THE URBAN ENVIRONMENT}

\section{Master Planning: Historical Interpretations}

Early Influences

Master planning as a concept has been used as a flexible term throughout history. It has been considered both as a "specific intervention" and an "abstract model" (Firley \& Grön, 2013, p. 13), resulting in many theoretical and built projects (Firley \& Grön, 2013). The master plan has focused on achieving an ideal urban environment through the organization and massing of built form. Historically, master planning has been conceived as a vision for a self-contained 'city', with its application ranging from neighbourhood design to city design. However, the use of the word 'master' usually has evoked a sense of immense scale, and has come to mean the "largest possible size of a plan's application" (Firley \& Grön, 2013, p. 15). Master planning has often stemmed from concerns of physical, social, and moral ills within existing urban environments. Ideas about the redevelopment of cities became increasingly prominent with the persistence of residential slum areas beginning in the nineteenth century. In some cases, slum housing conditions resulted in the redesign of cities and the creation of city-wide master plans, such as Baron Haussmann's redevelopment of Paris in the 1850s (Curtis, 2009). Jacob Riis' How the Other Half Lives and Jack London's The People of the Abyss gave first-hand accounts of the urban poverty and substandard housing plaguing nineteenth century cities, through the observation of slum areas within New York and London, England (Riis, 1890; Stein, 2001). The growth of urban slums in North America and Europe resulted in various master planning solutions to address the ineptitudes of city design. Ebenezer Howard's Garden City concept in 1902 was one such response to the substandard living conditions present in England's urban areas (Hall, 2014). It was premised on the idea of creating a union between the suburbs and the city, reflecting the increasing preference of the middle and upper classes to live within suburban settings (Ching, Jarzombek, \& Prakash, 2011). Howard's master plan was highly prescriptive, and focused on the concept of a core and a perimeter (Ching et al., 2011). It proposed a 6000-acre site that would contain a town at its centre, surrounded by a park, public buildings, and retail, designed to contain no more than 30,000 individuals (Ching et al., 2011). Industrial uses would exist at the outer ring of the town, surrounded by farm land (Ching et al., 2011). This model went beyond an abstract concept, and was applied to over 30 communities within England (Ching et al., 2011).

\section{Post World War II Master Planning Visions}

The ideas of 'good', 'efficient', or 'utopian' master plans have varied greatly over time, highly informed by subjective understandings. At the time surrounding the Second World War, government and non-government bodies alike continued to address issues of overcrowding, structurally inept housing, disease, and crime through master planning interventions (Solomon, 2007; Yale, 1944). The master planning of cities often used 'urban renewal' or slum clearance 
techniques to address these issues, through new strategies for the arrangement and massing of built form, which provided better air circulation, access to light, and improved sanitary conditions. These principles were epitomized in many of the works of Le Corbusier, a Swiss architect practicing in Paris (Blake, 1996). Many of Corbusier's utopian urban studies were conducted following the First World War, when France was suffering a severe housing crisis (Curtis, 2009). He criticized the master plans of his contemporaries, including the "horizontal spread of the Garden City" for its lack of efficiency (Ching et al., 2011, p. 731). Instead, Le Corbusier proposed the creation of vertical cities with towers placed within open space, clearly articulated through works such as the 1922 Ville Contemporaine (the Contemporary City for Three Million People) and the 1933 Ville Radieuse (Radiant City). Both Ville Contemporaine and Ville Radieuse involved the clearance of existing urban areas within Paris, and their replacement with "rows of identical cruciform skyscrapers" surrounding open space (Curtis, 2009, p. 731). This design was meant to amalgamate ideas of the city and the country, in order to transform the city into a park. In both of these master plans, Corbusier's focus on "light, greenery, air, cleanliness, and efficiency" stemmed from his concern for the substandard living conditions within the nineteenth century industrial city (Curtis, 2009, p. 247). Through his theoretical city designs, Corbusier aimed to promote improved hygiene and moral behaviour, creating a physical and social utopia (Curtis, 2009; ICE, 2010; Plunz, 1990). Le Corbusier's idea of standalone tower blocks in park-like green space became known as the 'tower in the park' model (Plunz, 1990; Stern, Mellins, \& Fishman, 1995). This involved utilizing tower forms that decreased the coverage of built form on-site, freeing up land for greenery and open space. This model gained popularity post World War II in European and North American cities (ICE, 2010; Plunz, 1990).

\section{Analysing the Master Plan}

In the face of various master planning ideologies, the second half of the twentieth century saw the formation of critical discussions surrounding master planning. This resulted in a variety of proposed urban design and planning lenses through which to analyze their effectiveness. Kevin Lynch's book The Image of the City (1960) proposed evaluating urban environments through an analysis of their 'legibility'. Lynch defined legibility as "the ease with which [the city's] parts can be recognized and can be organized into a coherent pattern" (Lynch, 1960, p. 2-3). Lynch proposed that legibility contributed towards good urban design (Taylor, 2009). He outlined 5 aspects of legibility: paths, edges, districts, nodes, and landmarks. Paths were defined as "channels along which" individuals move; edges as linear boundaries between 2 or more areas; districts as areas in the city unified by a common character; nodes as points within urban areas that act as the "intensive foci" or "cores"; and landmarks as physical elements that act as external points of reference (Lynch, 1960, p. 47). Though Lynch applied this method to mental maps, the method has been used by urban designers and planners as a set of guiding principles to evaluate the legibility of an urban environment (Taylor, 2009). The successfulness of a master plan has also 
been evaluated based upon the diversity of its programmed uses, highlighted through Jane Jacob's book The Death and Life of Great American Cities (1961). Jacobs stated that diversity was an essential aspect of good city design, and that it must be met by the presence of multiple uses and functions, short blocks, a variety of building periods and physical conditions, and a dense concentration of people (Jacobs, 1961). Though Jacobs highlighted design as an integral part of her ideal city planning vision, she advocated for a more organic approach to city building, compared to the prescriptive methods of Corbusier and Howard. Jacobs introduced the need for a human, or social component to master planning, arguing that cities must be planned for and reflect the diverse "tastes, skills, [and] needs" of city dwellers (Jacobs, 1961, p. 147).

\section{The Master Plan: A Function of Design Alone?}

In the contemporary context, the term 'master plan' has been considered "elitist", and is often associated with a sense "of authority and (potential) lack of flexibility" (Firley \& Grön, 2013, p. 15). This is likely a result of the heavily-prescribed design strategies associated with master plans created during the nineteenth and twentieth centuries. Questions surrounding the relationship between design and master planning have been discussed at great length since the mid-twentieth century. This was epitomized through the 1972 to 1976 demolition of Pruitt-Igoe, a 57-acre public housing project in St. Louis, Missouri (Bristol, 1991). In 1977, architectural theorist and critic Charles Jencks declared that the demolition of Pruitt-Igoe represented the 'death of modern architecture' (Bristol, 1991), correlating the demise of the master-planned housing project with its design. This opinion has been strongly reinforced by many of his contemporaries since the project's destruction (Bristol, 1991). In The Pruitt-Igoe Myth, Katharine Bristol argues that the perception that Pruitt-Igoe's architecture was the root cause of its demolition is a myth (Bristol, 1991); she states that Pruitt-Igoe was also influenced by urban redevelopment and housing policies of the time, and relevant social and economic contexts (Bristol, 1991). Through her analysis, Bristol acknowledges that master planning is a function of both urban design and urban planning and housing policy, and that the analysis of any project must take both into consideration.

Bristol's argument highlights a key flaw associated with contemporary understandings of master planning: that master planning is a result of urban design alone. In the contemporary context, the term 'master plan' is typically correlated with "the realm of urban design rather than [urban] planning" (Firley \& Grön, 2013, p. 15). The increasing focus on built form and the public realm rather than urban planning policy and housing policy reflects the siloed nature of the urban planning and urban design realms. This does not reflect the complex nature of a master-planned project, which is arguably tied to policies that reflect relevant social, economic, and political contexts. Urban planning and housing policy respond to pervading social issues, and should be considered equally as important to master planning as urban design. There is an absence of literature that discusses the role of both urban design and urban planning and housing policy in tandem, and their impact 
on the master planning of cities. The impact of urban design, urban planning policy, and housing policy on master-planned projects deserves further study by urban planners, urban designers, and academics. This paper aims to expand upon this topic, and contribute to limited existing research about master planning's relationship to urban design and urban planning, through a case study analysis of Stuyvesant Town in New York City and Regent Park in Toronto, Ontario. 


\section{NEW YORK CITY}

\section{The History of Town Planning in New York City \& The United States}

The notion of town planning existed within New York beginning in the early nineteenth century, and typically focused on improving living conditions for citizens. The first piece of legislation related to zoning appeared in 1804, establishing maximum housing densities as a way to address poor hygiene within existing residential areas (Plunz, 1990). In addition to zoning, urban housing policy was another dominant form of planning legislation within New York. The 1867 and 1901 Tenement House Act established "national standard[s] for tenement legislation" and aimed to reduce the number of substandard buildings within New York (Plunz, 1990, p. 59). The Building Zone Resolution of 1916 was the first major form of zoning policy in New York City, establishing heights, massing, and setbacks for a variety of building types (Plunz, 1990; Stern et. al, 1995). Zoning as a town planning concept became increasingly used in urban areas following the 1926 United States supreme court ruling supporting the "validity of zoning" (City of New York, 2016b).

Until the 1930s, New York City historically favoured mid-rise building design (Plunz, 1990). However, perceptions in the mid-1930s regarding aesthetics, economics, and social issues resulted in a shift towards high-rise design (Plunz, 1990). This was evident with the creation of the 1929 Multiple Dwellings Law, which regulated the alteration or new development of 'multiple dwellings' in New York. Multiple dwellings were defined as residences of "three or more families living independently of each other" (Committee on Housing, 1945, p. 5), and included tenements and apartment houses (Committee on Housing, 1945). The law outlined regulations related to fire protection, sanitation, and 'light and air', and specified how architectural design could contribute to safe and healthy living conditions through improved ventilation and reduced overcrowding (Committee on Housing, 1945; Plunz, 1990). High-rise housing design was also reinforced in 1935 with Le Corbusier's trip to Manhattan. Corbusier advocated his 'tower in the park' ideals through his proposal for Manhattan as a "city in a park" (Plunz, 1990, p. 240); this would only be possible through increasing Manhattan's tower heights and creating "megablocks" surrounded by green space (Plunz, 1990, p. 240). New York's shift towards the tower form was evident through the construction of several high-rise housing projects starting in the 1940s. New York's first high-rise tower project was the 1941 East River Houses development in East Harlem, a large superblock tower project that involved the clearance of tenement buildings (Plunz, 1990). By the end of the 1950s, New York City's Lower East Side had experienced an influx of 'tower in the park' developments, made possible through slum clearance (Plunz, 1990).

\section{The History of Slum Clearance Ideology in New York City \& The United States}

The use of slum clearance to enable affordable housing provision was highlighted within the United States of America through a variety of municipal, state, and national legislation. The lack 
of affordable housing, urban housing shortages, and the increase in tenement buildings in the early twentieth century resulted in a variety of housing policies in New York. The 1926 New York State Housing Law focused on the creation of housing for low-income families by placing monthly rent caps on rooms within Manhattan (Plunz, 1990). This document gave power to public limiteddividend companies to "exercise condemnation" in order to create affordable housing (Ford, 1971, p. 538). This law was amended in 1934, and gave way to the Municipal Housing Authorities Act. This act also focused on the promotion of affordable housing for low-income families, with the aim of reduced average rents through decreased construction costs and government-subsided housing (Plunz, 1990). It provided the powers of "purchasing, leasing, selling, and condemning property" (Ford, 1971, p. 640).

Ideas surrounding the use of slum clearance were prevalent across the United States in the 1930s and 1940s through 'urban redevelopment'. Slum clearance was viewed as a tool to create affordable housing, while remedying issues of overcrowding, inadequate housing, and high rates of disease, mortality, and crime (Yale, 1944). It aimed to improve physical environments and their associated social and health benefits (Yale, 1944). The term 'urban redevelopment' was used to describe this process of slum clearance and revitalization (Yale, 1944). Overall, urban redevelopment laws aimed to reduce existing issues associated with the replacement of new housing complexes, often through eminent domain (Yale, 1944). Impediments to urban redevelopment included high land costs and lack of interest from the construction industry in the adoption of large-scale, massproduced housing projects (Yale, 1944). Difficulties assembling the control of land, and costs of site acquisition and clearance were identified as the major impediments to slum clearance in the United States during the early twentieth century (Yale, 1944). To address this issue, some urban redevelopment laws offered tax abatements to parties involved in this process (Yale, 1944). The creation of the United States Housing Act in 1937 was a clear appropriation of the concept of urban redevelopment. The act was created to provide financial assistance towards the "elimination of unsafe and insanitary housing conditions, for the eradication of slums, [and] for the provision of decent, safe and sanitary dwellings for families of low income..." (USHA, 1937, p. 1). The act enabled the provision of federal loans for public housing projects in the form of low-rent housing and slum clearance projects (USHA, 1937). These sentiments were also echoed in the 1949 United States Housing Act, which acknowledged the need for private enterprise to contribute to urban housing development in the face of economic hardships (HHFA, 1950).

\section{Stuyvesant Town: Process, Policy, \& Urban Design}

In the early 1940s, New York City was experiencing an affordable housing shortage and a lack of sufficient capital to support the creation of urban housing infrastructure (Capeci Jr., 1978; Stern et. al, 1995). Suburban housing was no longer considered financially viable for many citizens, resulting in an increasing need for affordable housing within the city core. The mayor Fiorello 
H. La Guardia was determined to increase affordable housing stock within the city, as a method to address demand, and to rid the city of the slum developments that were creating unhealthy and "physically degenerated environment[s]" (Stern et. al, 1995, p. 283). This was exacerbated by financial strain at end of the Depression and surrounding World War II, limiting government revenue, and hindering the ability of the private sector to construct profitable middle-income housing (Bloom \& Lasner, 2015; Plunz, 1990). This prompted the City to create the necessary policy conditions for the private sector to invest in affordable rental housing, with the first urban redevelopment law in the United States: New York State's 1942 Urban Redevelopment Corporations Law (Capeci Jr., 1978; Yale, 1944). This law was amended in 1943 by the Hampton-Mitchell Amendment, which allowed New York City to use eminent domain for "private projects deemed by the city to serve a "public purpose"" (Bloom \& Lasner, 2015, p. 152). It gave municipalities the power to sell deteriorating areas to private companies for redevelopment (Goldfield, 2006). This law reflected the burgeoning interest in the use of private corporations for slum clearance and redevelopment processes. In particular, it was influenced by Robert Moses, the New York City Park Commissioner, who believed that the use of private capital could "stop the spread of slums and blight" (Bloom \& Lasner, 2015, p. 151), and address the demand for middle-income housing (Goldfield, 2006). The 1943 amendment was used by Metropolitan Life Insurance Company to realize 2 housing projects: Riverton in Harlem, and Stuyvesant Town on the City's Lower East Side (Stern et. al, 1995; Yale, 1944) [Figure 1].

Figure 1: Key Map of Stuyvesant Town, New York City

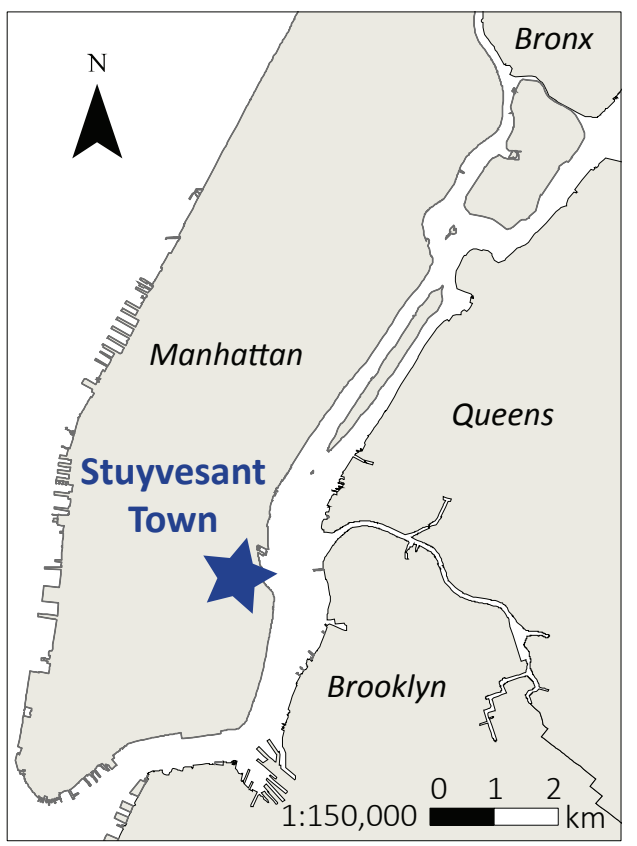

The desired site for Metropolitan Life's Stuyvesant Town was the home of an 18-block slum area known as the Gas House District, so named for the predominance of industrial uses amongst tenement buildings (Stern et. al, 1995; Zipp, 2006, Sept. 3). A study of conditions in the 1940 s revealed the substandard housing conditions in the district's 5 and 6-storey tenement buildings, with many of the buildings lacking heat, bathrooms, and requiring maintenance (Zipp, 2010). Framed as a blighted area that required revitalization, the Gas House District was soon replaced by Stuyvesant Town (Stuy Town), a master-planned private housing complex built between 1943 and 1949 (Stern et. al, 1995). The site was defined by First Avenue, Avenue C, East River Drive, East Fourteenth Street, and East Twentieth Street (Stern et. al, 1995). The development was built as affordable housing for middle-income citizens, and was not built to rehouse the residents of the Gas House District. Metropolitan 
Life (Met Life) voluntarily created a relocation process for the district's residents to help them find open market apartments and public housing (Stern et. al, 1995). However, due to their low incomes and the shortage of relocation housing, few housing matches were found by Met Life (Schwartz, 1993). Many of these residents self-relocated to other housing, including other slum areas within the City (Schwartz, 1993).

Figure 2: Aerial View of Stuyvesant Town, looking from East Fourteenth Street and Avenue C (Putzier, 2015, Oct. 29).

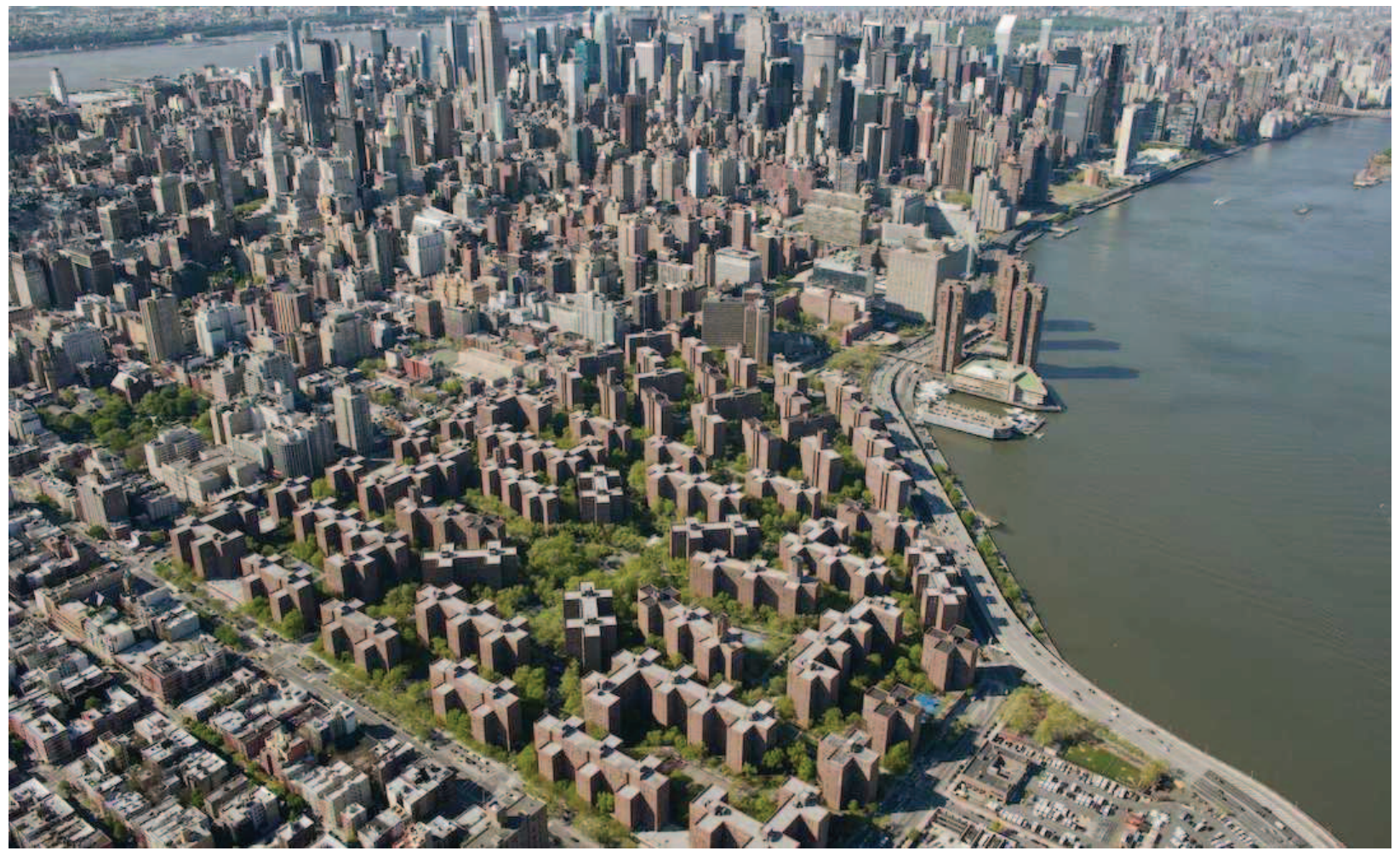

Stuyvesant Town was created as a 72-acre housing complex for 24,000 residents, with 8,755 apartment units. The design embodied a "symmetrical" and "ordered" 'tower in the park' model (Zipp, 2010, p. 104), with 35, 12 and 13-storey apartment towers arranged around formal parks and plazas (Firley \& Grön, 2013; Stern et. al, 1995) [Figure 2]. Its plan involved a minimalist design using simple red brick buildings, a style appropriated from the New York City Housing Authority's public housing developments (Zipp, 2010). The buildings were unadorned and given plain façades, with rows of individual windows (Zipp, 2010). They consisted of a range of "one to five standardized core units", grouped in cross and L-shapes (Zipp, 2010, p. 104). Consistent building spacing resulted in a site coverage of 25 percent, increasing access to light and air circulation compared to the former district's 70 percent coverage (Firley \& Grön, 2013). The landscaping included pathways, a central fountain, amenity spaces, and an abundance of greenery, evoking the image of a "suburb in the city" (Zipp, 2010, p. 104). Limited retail space was placed on the perimeter of the development facing the surrounding area, representing popular zoning ideologies (Bloom \& Lasner, 2015). The urban design of Stuyvesant Town created an internalized community, 
reinforced by the "walled town" created by apartment buildings and externally facing commercial buildings (Stern et. al, 1995, p. 282); this limited pedestrians and vehicles to 8 access points (Plunz, 1990). This was an intentional design technique that represented a desire to increase resident safety through minimizing "unwanted external intrusion" (Plunz, 1990, p. 255); this was also meant to discourage residents from interacting with surrounding communities (Plunz, 1990). The internalized design also incorporated interior walkways and avoided the use of throughstreets [Figure 3 \& Figure 4].

Figure 3: Fountain at Stuyvesant Oval

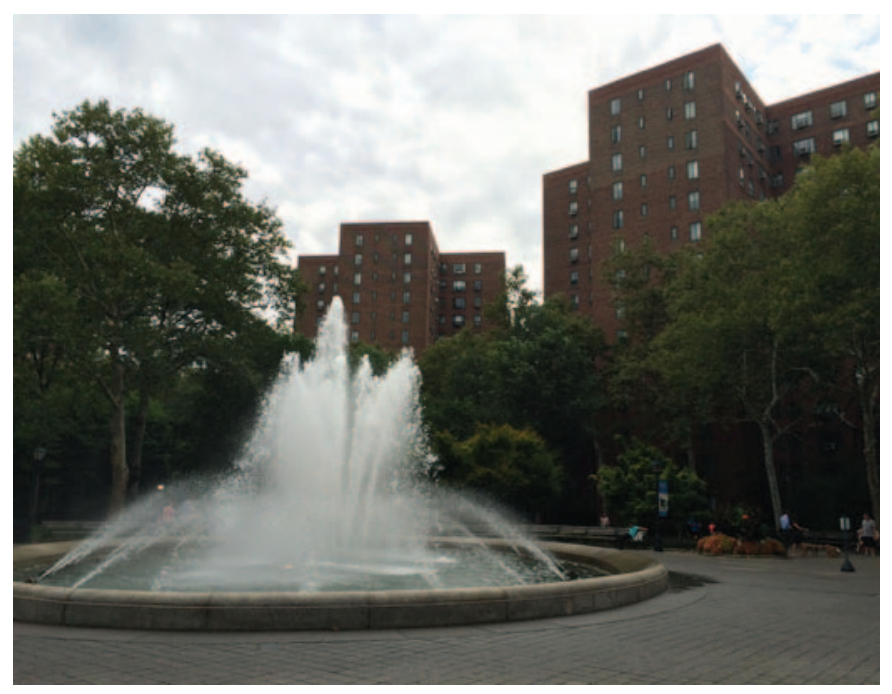

Figure 4: Wall Along East Fourteenth Street

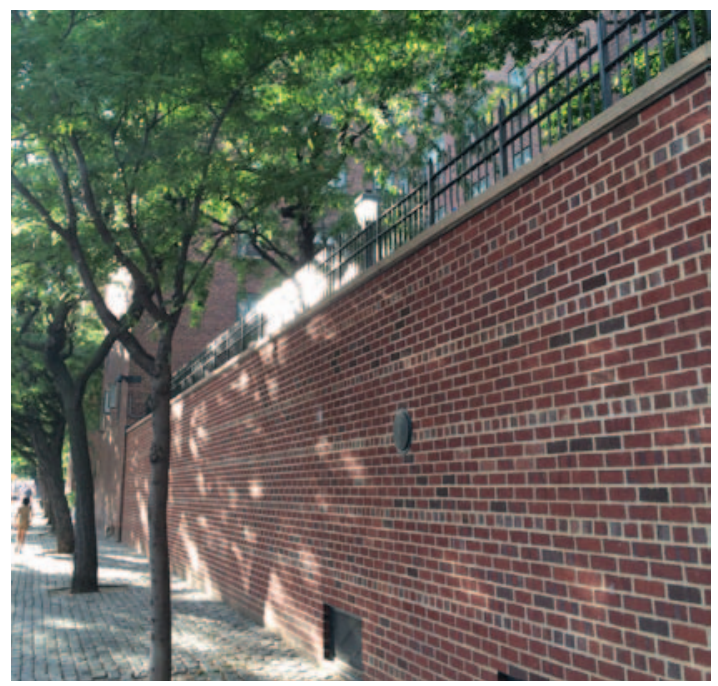

Stuyvesant Town has been considered one of the most significant projects constructed by the insurance industry during the post-war period (Goldfield, 2006). The project is one of the first examples of a public-private partnership used for municipal housing development in New York City (Capeci Jr., 1978). Metropolitan Life Insurance Company was the only private investor willing to realize Stuyvesant Town (Capeci Jr., 1978). Partnering with Metropolitan Life allowed the City of New York to share the financial costs and risks associated with the \$55 million development, including infrastructure and construction costs (Stern et. al, 1995). The City secured a municipal contract with Met Life, contributing 504,449 square feet of land, and using their powers of eminent domain to assist the investors to acquire the necessary lands (Capeci Jr., 1978). The land contributed by the City consisted of 19 percent of the site area (Capeci Jr., 1978). Additionally, the City formed an agreement that granted Metropolitan Life a tax stabilization for 25 years based on the area's assessed valuation in 1943, in exchange for limiting its profit to 6 percent on investment (Stern et. al, 1995). The exercise of tax exemption and eminent domain policies, and Met Life's control over tenant selection reflected "a sound, profitable investment" for the insurance company (Capeci Jr., 1978, p. 309), reducing their financial risk. 


\section{TORONTO}

\section{The History of Town Planning in Toronto \& Canada}

Comprehensive town planning was absent within the City of Toronto during most of the nineteenth and twentieth centuries. The city implemented its first building by-law in 1874, and was followed by approximately 800 by-laws and 3000 amendments, all of which lacked an association with a defined planning framework (Bruce, 1934). At the start of the twentieth century, Toronto's "stringent building regulations" were attributed for the existence of haphazard development, sprawling single-family suburban homes, and low-cost slum projects (Solomon, 2007, p. 20). Single-family homes were the predominant type of residential built form. With the plethora of unregulated development, the existence of tenement infrastructure became increasingly prominent. The concern for the sanitary and moral issues associated with tenement houses resulted in a 1914 by-law that permitted the health department to inspect homes and to require owners to "upgrade any sanitary facilities found wanting" (Solomon, 2007, p. 29); this resulted in the demolition of 1,600 homes between 1913 and 1918 (Solomon, 2007). By the 1930s, Toronto's existing building regulations focused on matters such as "space, number and size of windows, height of ceilings" and other "structural requirements" (Bruce, 1934, p. 69). However, the City's lack of zoning ordinances and the existence of various by-laws and amendments created an unclear direction in city planning, which continued post World War II (Bacon, 1984; Bruce, 1934). The desire for a singular and clear direction in city planning was articulated through the creation of Toronto's 1942 Draft Zoning By-Law. The by-law divided the City into residential, commercial, and industrial zones, and outlined specific regulations for permitted building uses, heights, frontages, and coverage values (ICZ, 1942). The by-law was created to eliminate the "confusion and uncertainty" related to current city planning, through the consolidation of all existing by-laws and amendments (ICZ, 1942, p. 24). The aim was to create "an intelligible and uniform pattern of land use regulation" within Toronto (ICZ, 1942, p. 24). The by-law was also a response to the City's blighted areas and the encroaching industrial sector. The by-law was never passed by Council, but clearly articulated the growing concern for unplanned development in the City, and the desire to improve substandard housing conditions within Toronto.

\section{The History of Slum Clearance Ideology in Toronto \& Canada}

The themes of healthy and safe housing conditions continued to be the driving force of many planning studies within Toronto during the 1930s and 1940s. The 1934 Report of the LieutenantGovernor's Committee on Housing Conditions in Toronto, also known as the 'Bruce Report', was one such response to the burgeoning number of slum areas within Toronto (Bruce, 1934). The report defined slums as areas with "unfit" or "unsatisfactory" housing conditions (Bruce, 1934, p. 1314), and established minimum standards of health and amenities to evaluate the City's residential areas (Bruce, 1934). Toronto's lack of a single authority in housing development added to the 
complexity of the issue; this impeded efficient and clear decision-making, in turn, jeopardizing the ability to ensure healthy and safe housing conditions. The Department of Public Health, The Department of Buildings, and The Department of City Planning all played a role in the regulation of Toronto's housing conditions. The Department of Health had the ability to condemn structures "unfit for human habitation" (Bruce, 1934, p. 68); the Department of Buildings enforced the City's building by-law, which regulated the structural integrity of new buildings; and the Department of City Planning was responsible for street and traffic problems, subdivision plans, and other matters related to city growth (Bruce, 1934).

The Bruce Report identified the areas of 'Moss Park' (Cabbagetown) and 'the Ward' as existing slum areas (George, 2010). In addition to identifying these substandard areas, the report also proposed hypothetical redevelopment strategies. One block within Moss Park, "bounded by Oak, Dundas, Sackville and Sumach Streets" (Bruce, 1934, p. 94), was used as a possible redevelopment area. This priority area included buildings with low property values, many below the minimum health standard, and many barely passing the minimum amenities standard (Bruce, 1934). The report proposed 3 possible designs for this area that aimed to address overcrowding, health and safety, and amenity deficiencies. They also reflected knowledge of Corbusier's 'tower in the park' model through their efficient use of space and "orderly arrangement of buildings" (Bruce, 1934, p. 98). Similarities between the 3 designs included the removal of through-streets and their replacement with interior walkways, the introduction of central green space and trees, and the use of large blocks of buildings, some of which faced courtyards and parks. The proposed built form was moderately low density, ranging from 1 to 3-and-a-half-storeys. The reluctance to incorporate higher density buildings popular in European cities reflected the general aversion in Toronto to this type of built form (Bruce, 1934). The report concluded with 4 recommendations for future action: the creation of a City Planning Commission with the sole authority for municipal planning; the clearance of all existing substandard housing; the creation of projects for slum clearance and low-cost housing provision; and a partnership between the municipal, provincial and federal governments to achieve these recommendations. The Report of the LieutenantGovernor's Committee on Housing Conditions in Toronto was an influential urban planning report for Toronto. The report spurred a campaign of slum clearance in Toronto that started a dialogue about "civic responsibility", "federal obligation" and new standards of "fitness" for low-income housing (George, 2010, p. 103). These ideals were reflected in Toronto's Master Plan of 1943 (George, 2010).

The 1943 Master Plan for the City of Toronto and Environs proposed a 30-year plan for "future growth and development" (CPB, 1943, p. 1), and represented the first attempt to plan at a metropolitan scale for the City of Toronto (White, 2007). The plan proposed to renew the city through the revitalization of substandard areas, and in its place create new housing, parks and 
open space, and an updated transportation network connecting the city and the suburbs (White, 2007). The plan acknowledged the need for controlled development, through zoning regulations that would promote satisfactory living conditions. The plan recommended the demolition of residential areas south of College Street, and redevelopment in the form of multiple family dwellings (CPB, 1943); this was to be undertaken by the public sector, and would be the fiscal responsibility of the provincial and federal governments (CPB, 1943). Many of these principles reinforced the ideas of the Bruce Report (George, 2010). Similar to the Bruce Report, the plan identified a 41-acre site in Cabbagetown, defined by Parliament Street, Gerrard Street, Dundas Street, and River Street, as an ideal location for low-income public rental housing (CPB, 1943). It recommended closing through-streets in order to facilitate a 2-storey superblock and increased open space. Though the plan was not implemented, it reiterated the need for improved housing conditions within the City of Toronto.

An urban housing crisis in the mid-1940s continued discussions about planning Canadian municipalities (James, 2010). Ideas regarding slum clearance and redevelopment present within the Bruce Report and the 1943 Master Plan were acknowledged legislatively with the creation of the 1944 National Housing Act (HAT, 1951). Section 12 of the act permitted the provincial government to provide grants to a municipality towards the "clearance, replanning, rehabilitation and modernization" of slum areas (HAT, 1951, p. 3). The grants were only possible if the municipality sold the land to a limited-dividend housing corporation or a life insurance company, in exchange for the construction of a rental housing project (HAT, 1951). The National Housing Act was integral in the development of large-scale rental housing projects, including Toronto's Regent Park (HAT, 1951).

\section{Regent Park: Process, Policy, \& Urban Design}

Since the development of the Bruce Report, the "unhealthy conditions" in the Moss ParkCabbagetown area had "been under fairly constant observation" (Carver, 1946, p. 1). The area's narrow, busy streets posed safety concerns for children and did not conform to fire regulations, and its single-family row houses were overcrowded and in poor structural condition (Bruce, 1934; James, 2010). A formal response to these poor living conditions and the post-war housing shortage finally surfaced in the late 1940s through the creation of Regent Park (James, 2010). In 1947, City Council put forward a vote to the ratepayers regarding the redevelopment of the area bound by Gerrard Street, Shuter Street, River Street, and Parliament Street (MTHA, 1962; THA, 1950). The vote passed, with 62 percent in favour of the redevelopment soon to be known as Regent Park North (MTHA, 1962; THA, 1950). Upon completion, the Regent Park complex would consist of 2 major sections: Regent Park North and Regent Park South. The development of Regent Park South was deferred until construction on Regent Park North had begun (MTHA, 1962). The entire project was built between 1948 and 1957 (James, 2010). 
The realization of Regent Park required the demolition of parts of Cabbagetown (James, 2010), and was "the first serious proposal to undertake large-scale slum clearance in a Canadian city" (Carver, 1946, p. 1). For the Regent Park North development, the clearance process required that homes were not torn down until alternative housing arrangements were found for existing residents (HAT, 1951). For Regent Park South, priority in rehousing was given to residents living on the site prior to redevelopment, and those families with the highest need (MTHA, 1962); upon completion, all on-site residents were rehoused in the new buildings (TDD, 1971). Regent Park North and South constituted approximately 69 acres of land, creating residences for 10,000 people just north of Toronto's downtown core (James, 2010) [Figure 5].

Figure 5: Key Map of Regent Park, Toronto

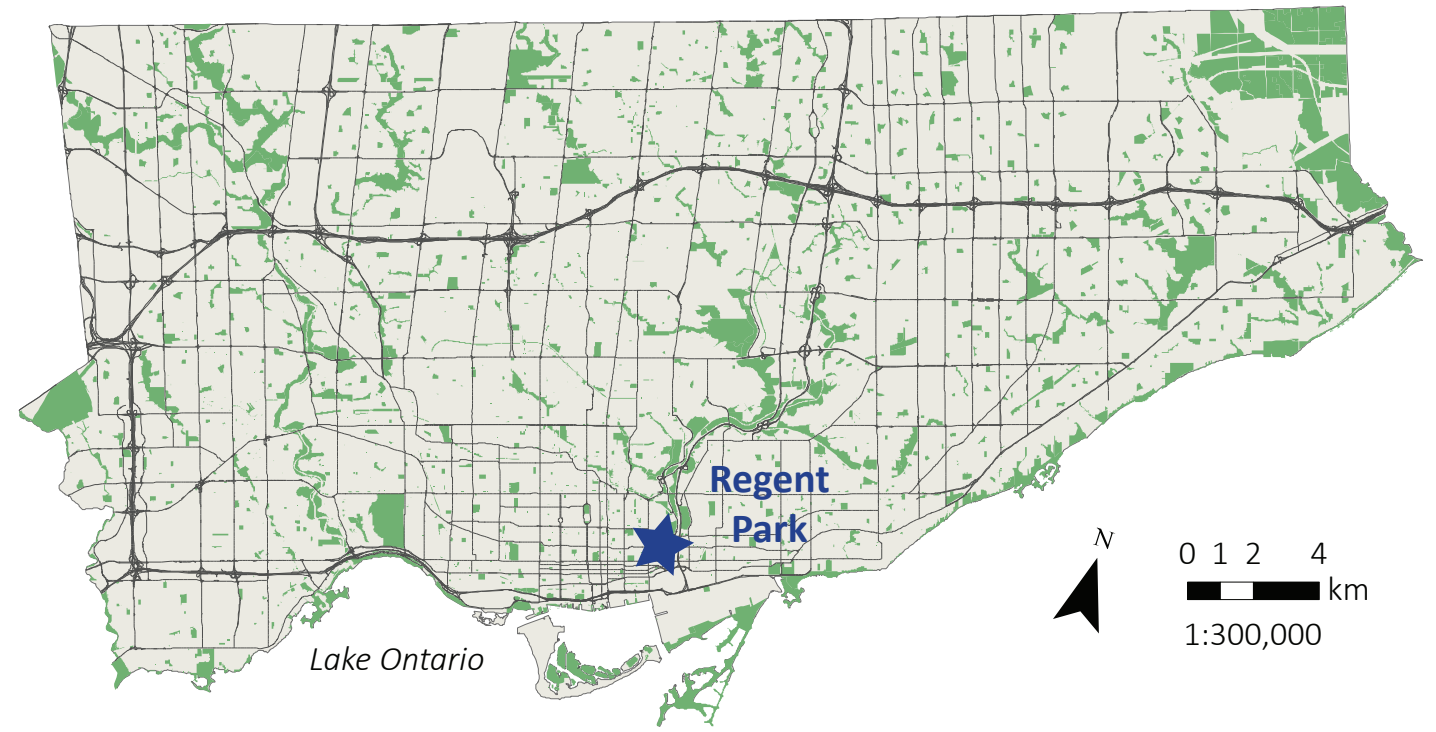

Regent Park North and South were designed using a superblock plan, "with all internal streets eliminated and no through traffic permitted" (HAT, 1951, p. 10), in order to increase open space and to promote increased safety for residents (THA, 1950). Through site design, vehicular traffic was limited to boundary streets, allowing internal areas to be used for interior walkways, designated green space, and parks (HAT, 1951). Regent Park North was a 42.5-acre development bounded by Dundas Street to the south, Gerrard Street to the north, Parliament Street to the west, and River Street to the east (THA, 1950). The plan of Regent Park North consisted of row houses, 3-storey apartment buildings containing either 48 or 54 units, and 6-storey buildings containing 72 units (Rose, 1958). In total, Regent Park North consisted of 1,289 residential units within row house buildings and apartment buildings (Rose, 1958), with the majority of buildings surrounding open space (HAT, 1951; Rose, 1958). Regent Park North was a phased project, with the eastern section completed in 1952, the central section in 1955, and the western section in 1957 (Rose, 1958). Regent Park South was defined by Dundas Street to the north, Shuter Street to the south, Regent Street to the west, and River Street to the east. Regent Park South was a 26.2acre development consisting of row housing and high-rise apartments, with 732 total units: 253 
low-rise row housing units and 479 apartment units (MTHA, 1962). Apartment buildings were grouped as 5, 14-storey high-rises (TDD, 1971). High-rise buildings were placed at the centre of Regent Park South, at different angles and with a large setback from the main road (TDD, 1971). The remainder of Regent Park South was designed with low-rise row houses "grouped in rows and courts" (MTHA, 1962, p. 8; TDD, 1971). Apartment towers were designed as slab buildings with skip level apartments- 2-storey units that provided "through ventilation" and minimized the number of public hallways that needed to be maintained (MTHA, 1962, p. 36). Several nonresidential uses existed within Regent Park South, including 2 churches, a community centre, day care, public school, heating plant, and a few stores (TDD, 1971) [Figure 6].

Figure 6: Aerial View of Regent Park North and South, Looking East, 1980-1988 (City of Toronto Archives, 2016).

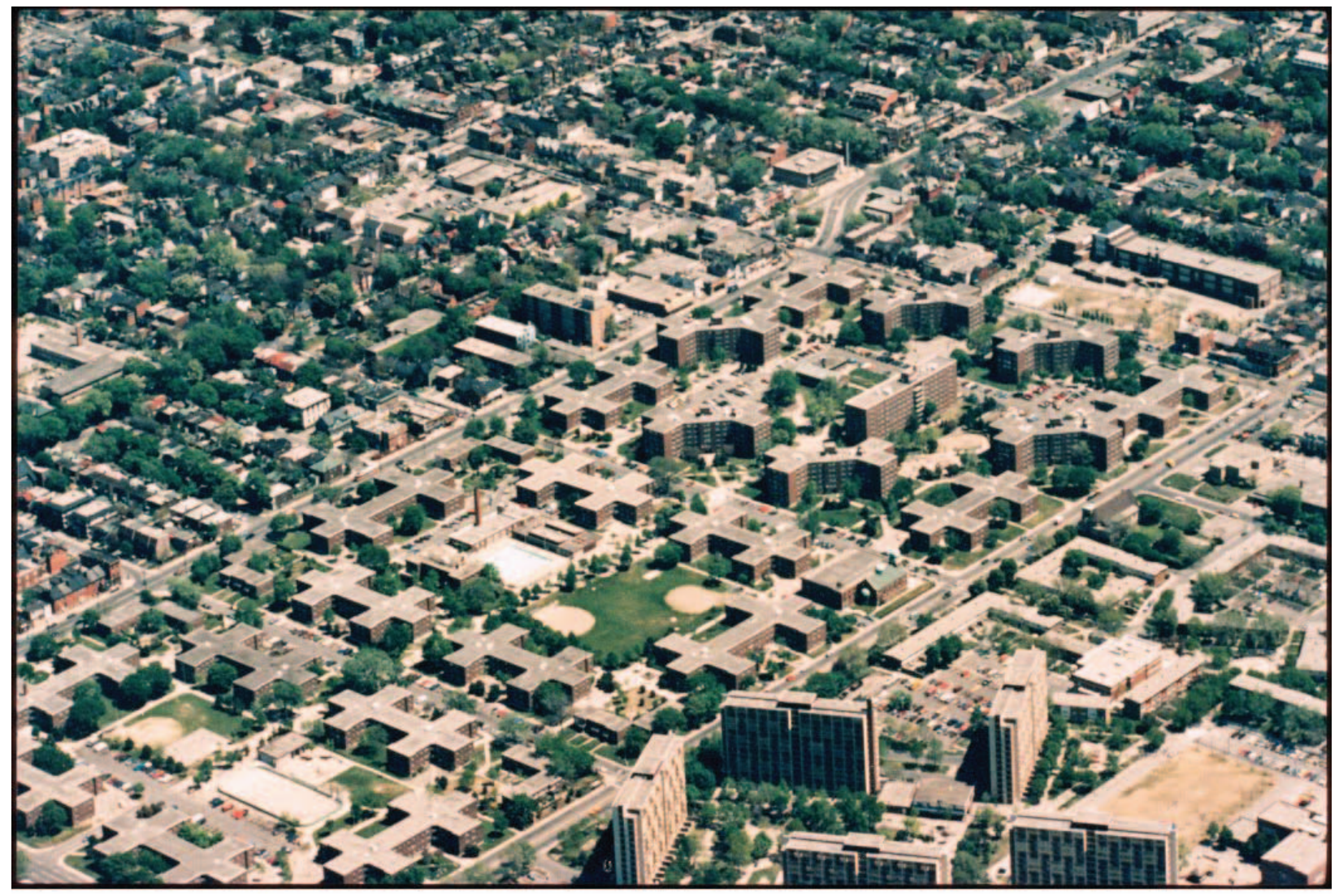

The project costs for Regent Park North and South totaled \$32,552,000: \$17,072,000 for Regent Park North, and $\$ 15,480,000$ for Regent Park South (MTHA, 1962; TDD, 1971). Both projects were funded by the municipal, provincial, and federal governments. Regent Park North was funded primarily by the City, with $\$ 14,312,000$ from the City, $\$ 1,398,000$ from the province, and $\$ 1,362,000$ from the federal government (MTHA, 1962). The majority of funding for Regent Park South was allocated to the federal government; the federal government contributed $\$ 10,690,000$, compared to the provincial and municipal contributions of $\$ 2,950,000$ and $\$ 1,840,000$ (TDD, 1971). 


\section{MASTER PLAN ANALYSIS: PROCESS, POLICY, \& URBAN DESIGN}

\section{Process}

Both Stuyvesant Town and Regent Park were produced from a desire to create safe, affordable housing during a time of post-war urban housing shortages, increasing slum areas with substandard housing conditions, and insufficient municipal government revenue. For Stuyvesant Town, affordable housing was realized through private housing for middle-income citizens. In 1940s New York, slum clearance was a common tool used to remove blighted areas from the City. In the case of Stuyvesant Town, the process of slum clearance and redevelopment was given priority over rehousing low-income residents living in the Gas House District. From the mid-1930s to 1950s, the City of Toronto was also experiencing debates surrounding how to address deteriorating residential areas within the City. Like New York City, this resulted in a shifting ideology towards slum clearance, which was thought to improve public health and safety, providing a better way of life for Torontonians. Regent Park was the first large-scale slum clearance project in a Canadian City (Carver, 1946); in contrast to Stuyvesant Town, it created affordable public housing for lowincome citizens, rehousing existing residents living on the project site. Both Stuyvesant Town and Regent Park were composed entirely of affordable housing units. Both New York City and Toronto were similarly motivated by notions of slum clearance, but the development processes used to create Stuyvesant Town and Regent Park greatly differed [Table 1]. Stuyvesant Town was one of the first public-private partnerships for municipal housing development within New York City.

Table 1: Development Processes for Stuyvesant Town and Regent Park

\begin{tabular}{|l|l|l|}
\hline \multicolumn{1}{|c|}{ STUVVESANT TOWN } & \multicolumn{1}{c|}{ REGENT PARK } \\
\hline Development Process & Slum Clearance & Slum Clearance \\
\hline Relocation Process & $\begin{array}{l}\text { Relocated existing tenants to } \\
\text { other developments }\end{array}$ & $\begin{array}{l}\text { Relocation and rehousing of } \\
\text { existing residents }\end{array}$ \\
\hline Target Residents & Middle-income & Low-income \\
\hline Public vs. Private & Private development & Public development \\
\hline Development Model & $\begin{array}{l}\text { Public-private partnership, } \\
\text { enabled through eminent } \\
\text { domain and tax exemption }\end{array}$ & Social housing \\
\hline Parties Involved & $\begin{array}{l}\text { City of New York and } \\
\text { Metropolitan Life Insurance } \\
\text { Company }\end{array}$ & $\begin{array}{l}\text { All levels of government: } \\
\text { municipal, provincial, and } \\
\text { federal }\end{array}$ \\
\hline Cost & \$55,000,000 USD (1943) & $\begin{array}{l}\text { \$32,552,000 CAD; } \\
\text { RPN: \$17,072,000 CAD (1947) } \\
\text { RPS: \$15,480,000 CAD (1952) }\end{array}$ \\
\hline
\end{tabular}

Note: Abbreviations are as follows: Regent Park North (RPN) \& Regent Park South (RPS) 
This process converted publicly owned lands into private residential lands, owned and operated by a private insurance company. The City's partnership with Metropolitan Life involved exercising the powers of eminent domain and tax exemption in order to secure the project. Regent Park's creation was a result of a partnership between the municipal, provincial, and federal government, creating a public housing complex under government control. New York's approach to slum clearance also reflected the balance of political power in 1940s New York, representing Robert Moses' vision for the redevelopment of New York City (Goldfield, 2006). The reliance on the private sector resulted in a discriminatory tenant selection process that prohibited individuals of African American descent, due to the belief that their tenancy would jeopardize the project's financial prosperity (Capeci Jr., 1978). In spite of a blatant disregard of state-led civil rights laws, mayor La Guardia permitted the development of Stuyvesant Town. Though New York City and Toronto were motivated by similar social and economic realities, the manner in which they realized affordable housing reflects each city's varying perceptions of civic responsibility and the public interest.

Varying ideas of affordability can be further illustrated through a comparison of socio-economic statistics of residents living within Stuyvesant Town and Regent Park [Table 2]. In 1970, Stuyvesant Town contained 24,807 residents, with an average income of $\$ 19,053$. Regent Park North had a population of 5,064 in 1968, whereas Regent Park South had a population of 3,917 in 1960. Average annual household income totalled $\$ 4,320$ for the North (1968) and $\$ 3,060$ for the South (1960). Average monthly rental costs were $\$ 67.82$ in Regent Park North (1964), and \$68.00 in Regent Park South (1960), compared to Stuyvesant Town's average monthly rental cost of $\$ 68.63$ (1949). Evidently, this data was collected for a variety of years following the development of

Table 2: Socio-Economic Characteristics of Stuyvesant Town and Regent Park

\begin{tabular}{|l|l|l|l|}
\hline STUYVESANT TOWN & \multicolumn{1}{|c|}{ REGENT PARK } & \multicolumn{1}{|c|}{$\begin{array}{c}\text { Inflated Values, } \\
\text { 2016 Dollars }\end{array}$} \\
\hline Number of Residents & 1970: 24,807 & $\begin{array}{l}\text { RPN (1968): 5,064 } \\
\text { RPS (1960): 3,917 }\end{array}$ & N/A \\
\hline $\begin{array}{l}\text { Average Monthly Rental } \\
\text { Cost }\end{array}$ & 1949: \$68.63 & $\begin{array}{l}\text { RPN (1964): \$67.82 } \\
\text { RPS (1960): \$68.00 }\end{array}$ & $\begin{array}{l}\text { RPN (1964): \$528.83 } \\
\text { RPS (1960): \$557.60 } \\
\text { STUY (1949): \$683.74 }\end{array}$ \\
\hline $\begin{array}{l}\text { Annual Average } \\
\text { Household Income }\end{array}$ & 1970: \$19,053 & $\begin{array}{l}\text { RPN (1968): \$4,320 } \\
\text { RPS (1960): \$3,060 }\end{array}$ & $\begin{array}{l}\text { RPN (1968): \$29,679.57 } \\
\text { RPS (1960): \$25,092.00 } \\
\text { STUY (1970): \$116,434.95 }\end{array}$ \\
\hline $\begin{array}{l}\text { Annual Rent-to-Income } \\
\text { Ratio, 2016 Dollars }\end{array}$ & & $\begin{array}{l}\text { RPN: 21.4\% } \\
\text { RPS: 26.7\% } \\
\text { STUY: 7.05\% }\end{array}$ \\
\hline
\end{tabular}

Note: Inflated 2016 monetary values are based on the data from the Bank of Canada (BOC) and the United States Bureau of Labor Statistics (BLS) inflation calculators. Based on inflation calculator data as of March 18, 2016. Note: Abbreviations are as follows: Regent Park North (RPN), Regent Park South (RPS), \& Stuyvesant Town (STUY) Sources: BLS, 2016; BOC, 2016; Glass, Woldoff, \& Morrison, 2014; HAT, 1951; TDD, 1972; TDD, 1971. 
Stuyvesant Town and Regent Park. Many of these statistics can be more clearly understood when taking into consideration their monetary value in the current year of 2016. Average monthly rental values translate to $\$ 528.83$ for Regent Park North (1964), \$557.60 for Regent Park South (1960), and $\$ 683.74$ for Stuyvesant Town (1949). Average household income translates to $\$ 29,679.57$ for Regent Park North (1968), \$25,092.00 for Regent Park South (1960), and \$116,434.95 for Stuyvesant Town (1970). Though a variety of years are used for the above data, one clear point is expressed: residents of Stuyvesant Town made significantly more money than residents of both Regent Park North and South. For example, based on inflated 2016 values, the annual incomes for residents in Stuyvesant Town in 1970 was approximately $\$ 86,755$ more than residents residing in Regent Park North in 1968. Regent Park North residents had a significantly higher income than those living in Regent Park South. However, monthly rental costs were similar between Stuyvesant Town and Regent Park, with Stuyvesant Town's rent between \$126 and \$155 higher than that of Regent Park. Based on the inflated 2016 values, the annual rent-to-income ratio, the amount of annual household income spent on annual rent, was 7\% for Stuyvesant Town residents, compared to $21 \%$ for Regent Park North, and $27 \%$ for Regent Park South. This comparison highlights the different interpretations of the term 'affordable housing' used with these developments. Regent Park's low-income residents paid a significantly higher proportion of their annual income on rent than Stuyvesant Town's middle-income residents.

\section{Policy}

Although Stuyvesant Town and Regent Park were premised on differing ideas of affordability, both projects were a clear result of policy measures [Table 3]. Stuyvesant Town and Regent Park were a

Table 3: Policies Influencing the Development of Stuyvesant Town and Regent Park

\begin{tabular}{|l|l|l|}
\hline \multicolumn{1}{|c|}{ STUYVESANT TOWN } & \multicolumn{1}{|c|}{ REGENT PARK } \\
\hline Central Issues to Address & $\begin{array}{l}\text { Substandard housing conditions } \\
\text { in slum areas; affordable urban } \\
\text { housing shortage }\end{array}$ & $\begin{array}{l}\text { Substandard housing conditions in } \\
\text { slum areas; affordable urban housing } \\
\text { shortage }\end{array}$ \\
\hline $\begin{array}{l}\text { Official Policies, Municipal } \\
\text { Level }\end{array}$ & $\begin{array}{l}1926 \text { New York State Housing } \\
\text { Law; 1937 Municipal Housing } \\
\text { Authorities Act }\end{array}$ & N/A \\
\hline $\begin{array}{l}\text { Official Policies, State and/ } \\
\text { or Provincial Level }\end{array}$ & $\begin{array}{l}\text { New York State's 1942 Urban } \\
\text { Redevelopment Corporations Law }\end{array}$ & N/A \\
\hline $\begin{array}{l}\text { Official Policies, National } \\
\text { Level }\end{array}$ & 1937 United States Housing Act & 1944 National Housing Act (Canada) \\
\hline Planning Studies & N/A & $\begin{array}{l}\text { 1934 Report of the Lieutenant- } \\
\text { Governor's Committee on Housing } \\
\text { Conditions in Toronto (Bruce } \\
\text { Report); 1943 Master Plan for the } \\
\text { City of Toronto and Environs }\end{array}$ \\
\hline
\end{tabular}


direct result of urban planning policies, housing policies, and urban planning studies surrounding affordable housing provision and slum clearance processes. The need for higher quality affordable housing was highlighted in New York City through legislation such as the 1926 New York State Housing Law and the 1937 Municipal Housing Authorities Act, whose policies reflected the desire for safe and affordable urban housing. Unlike New York City, the City of Toronto was void of housing policies expressly supporting affordable housing development and slum clearance until the mid-1940s. This, in addition to the City's lack of a comprehensive zoning system, resulted in pockets of substandard housing. Contrary to New York's various legislative policies, Toronto had several informal urban planning studies that highlighted the need for the redevelopment of its blighted areas, including the 1934 Report of the Lieutenant-Governor's Committee on Housing Conditions in Toronto (the Bruce Report) and the 1943 Master Plan for the City of Toronto and Environs. These documents were a catalyst for discussion about improved living conditions for citizens living within slum dwellings, and promoted the creation of new, affordable residential developments. These ideas were highlighted at the national level with the 1937 United States Housing Act, and Canada's 1944 National Housing Act. Both documents outlined policies that supported the clearance and redevelopment of slum areas. Discussions surrounding urban redevelopment had been occurring in the United States during the 1930s and 1940s, resulting in many state laws encouraging this process. The creation of Stuyvesant Town's affordable housing was enabled through New York State's 1942 Urban Redevelopment Corporations Law, which permitted the involvement of the private sector in the creation of urban housing within New York City. For Toronto, the National Housing Act created a much-needed legislative framework for urban redevelopment, reflecting recommendations of the Bruce Report and the 1943 Master Plan. Recommendations surrounding the redevelopment of parts of Cabbagetown and Moss Park influenced the development of Regent Park, in addition to policies from the National Housing Act.

\section{Urban Design}

The desire to address built form issues associated with urban slum areas and to increase urban housing provision was reflected in the urban design of both Stuyvesant Town and Regent Park. An urban design analysis of the built form typologies and organization, circulatory patterns, parks and open space, amenities, and land uses highlights the similarities and differences between Stuyvesant Town and Regent Park.

\section{Acreage \& Scale of Design}

Both Stuyvesant Town and Regent Park were planned as residential neighbourhoods. Though both complexes have similar acreage values- 72 acres for Stuyvesant Town and 69 acres for Regent Park-Stuyvesant Town was master-planned at a much larger scale. This is clearly indicated through the density of each project's built form, and the resident population capacity; Stuyvesant Town was made for 24,000 residents, and Regent Park for 10,000 residents. This results in a 
density of approximately 334 people per acre for Stuyvesant Town and 145 people per acre for Regent Park.

\section{Built Form}

Stuyvesant Town's master plan features higher density than Regent Park. Stuyvesant Town's

Figure 7: Stuyvesant Town Master Plan, New York City

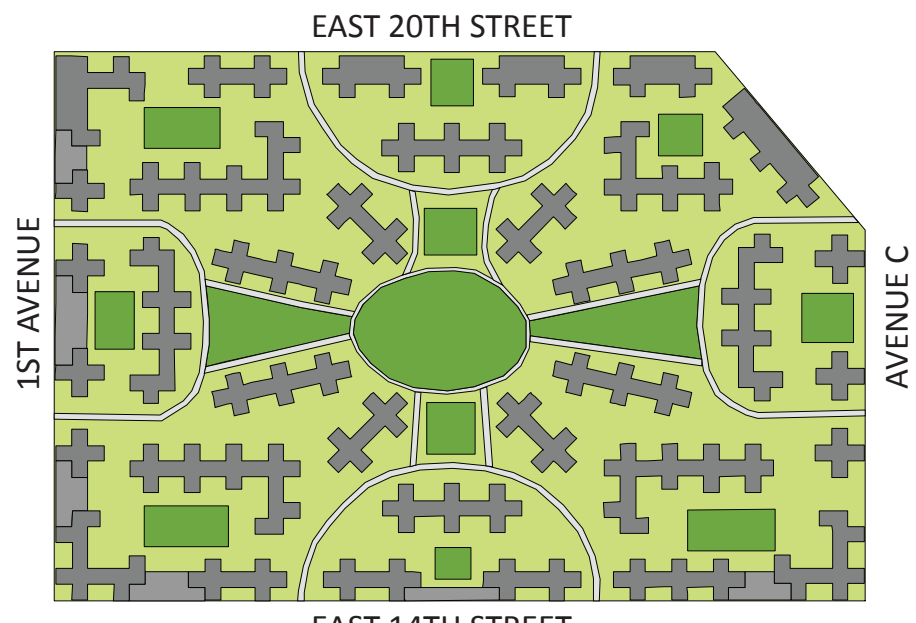

EAST 14TH STREET

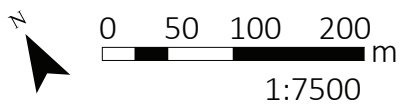

Figure 8: Regent Park Master Plan, Toronto built form consists of 35 cross and L-shaped high-rise buildings of 12 to 13-storeys [Figure 7], whereas Regent Park consists of much lower density [Figure 8]. Regent Park's built form includes a high proportion of low-rise row houses, and apartment buildings of 3, and 6-storeys; 5 buildings in Regent Park South are 14-storeys. The variation in residential density likely reflects the perceptions in New York City and Toronto regarding high-rise built form. Most of the buildings in Regent Park North use the cross-shape form present within Stuyvesant Town, whereas the buildings in Regent Park South are

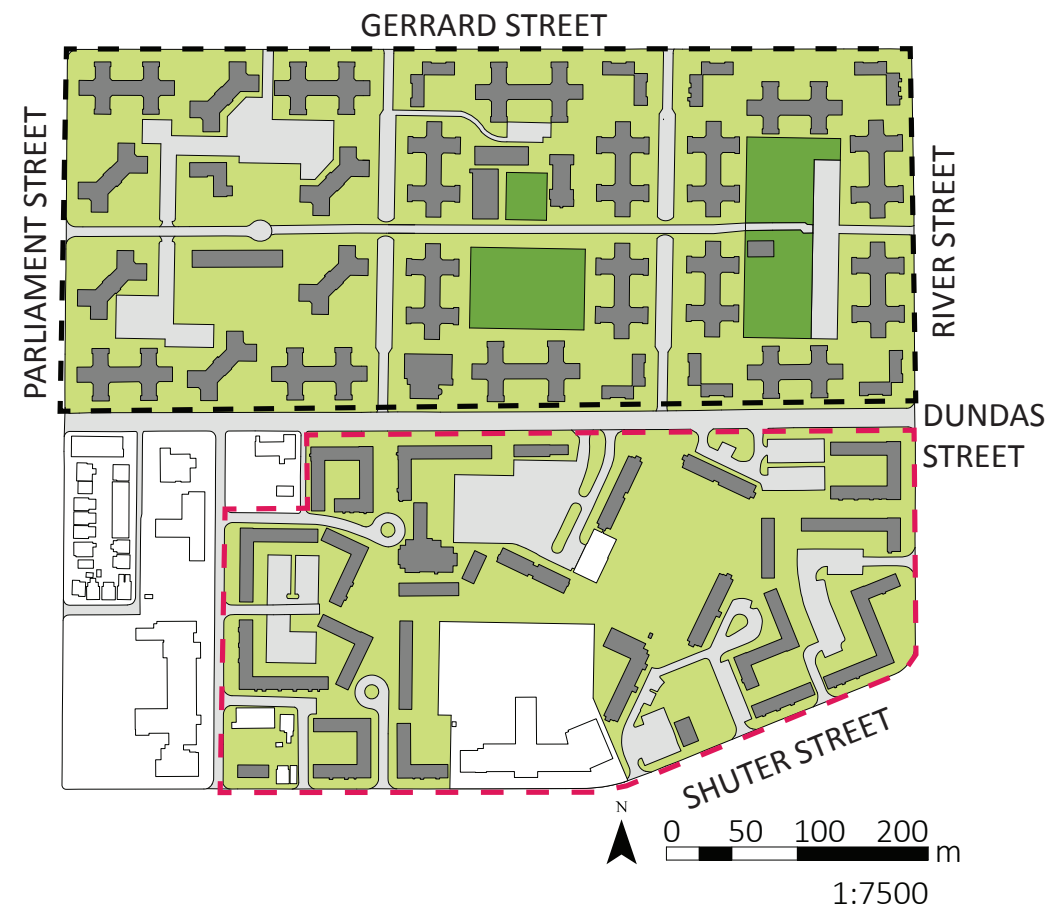

r I Regent Park North Boundary

I 7 Regent Park South Boundary

Built Form

Circulation

Informal Green Space

Formal Park or Plaza

Externally Owned Built Form and Lands 
L-shaped. Based upon the included master plan, the Regent Park master plan has a total of 62 residential buildings of varying shapes and sizes, with 36 in Regent Park North, and 26 in Regent Park South; this excludes the few commercial and institutional buildings within the development's boundaries.

\section{Tower in the Park}

The international presence of Le Corbusier's utopian 'tower in the park' model is clear through the comparison of his overarching design principles with both master plans. Corbusier believed that the creation of vertical cities was the solution to solving urban housing crises, and substandard housing conditions present in industrial cities. The creation of a higher density built form set within significant open space in both Stuyvesant Town and Regent Park reflects Corbusier's vision to varying degrees. Stuyvesant Town more closely appropriates Le Corbusier's 'tower in the park' model than Regent Park. Stuyvesant Town's design epitomizes the creation of a vertical city composed of high-rise buildings with identical façade design, and a low coverage value, reflecting Le Corbusier's vision of Manhattan as a city in a park. This results in a more efficient urban design, with a high residential density as well as open space, greenery, and amenities. Stuyvesant Town's buildings are focused around formal parks and plazas. This includes the central 'Stuyvesant Oval', from which buildings radiate outwards at angles surrounding this space and adjacent park spaces. Regent Park also incorporates the 'tower in the park' ideology, but at a lesser scale than Stuyvesant Town. Regent Park's design features fewer formal green spaces than Stuyvesant Town, and fewer high-rise towers. The aversion to high-rise buildings in Toronto stated in the Bruce Report is evident in the design of Regent Park, through the predominance of low density buildings. However, the notion of efficiency is still present through increased density compared to the site's former design, which featured low density row houses. This allowed for increased open space for parks, trees, and other amenity space, improving access to light, air, and greenery. Overall, the arrangement of Stuyvesant's Town built form appears more carefully organized than that of Regent Park, due to the consistent placement of identical towers surrounding formal green spaces. Though Regent Park North's built form typically corresponds with the north-south, east-west orientation of the development's internal circulation and Toronto's street network, the organization of Regent Park South is haphazard, with buildings arranged at various angles.

\section{Insular Design}

Urban design strategies for Stuyvesant Town and Regent Park result in two insular, "introverted" master-planned projects (Plunz, 1990, p. 80), with housing facing inwards, away from their surroundings. Stuyvesant Town's wall of built form along its perimeter plays a large role in its isolation from the rest of New York City. The insular nature of both housing projects is also closely related to their interior and exterior circulation. The removal of through-streets to create Regent Park results in limited pedestrian and vehicular circulation. Interior circulation is restricted to surface 
parking access around the perimeter of Regent Park North and South. Pedestrian circulation in Regent Park is practically non-existent, with the exception of an east- west pathway within Regent Park North. Stuyvesant Town's circulatory design also lacks through-streets, reinforcing that the neighbourhood is privately owned. Its circulation is based upon 8 access points, 2 on each of its main bounding streets. The circulation routes for each master plan reflects intentional safety measures implemented in their design. Regent Park's design was meant to improve children's safety by reducing vehicular traffic. Stuyvesant Town's design intended to improve safety by discouraging 'outsiders'; this was highlighted through panopticon-inspired security at the central 'Stuyvesant Oval' plaza, reinforcing control through design from the "inside out" as well as the "outside in"” (Plunz, 1990, p. 255). Arguably, the master plan of Regent Park provides better accessibility to the surrounding City than the design of Stuyvesant Town, particularly in Regent Park North. Regent Park's division into 2 distinct sections- North and South- permits better access to the City through the presence of Dundas Street. This creates 2 sub-areas of 26.2 and 42.5 acres compared to the 72 acre, walled-in Stuyvesant Town.

\section{Lynchian Analysis}

A Lynchian analysis of both Stuyvesant Town and Regent Park underscores the differences in the urban design of both master-planned housing projects. The existence of paths, districts,

Figure 9: Lynchian Analysis of Stuyvesant Town
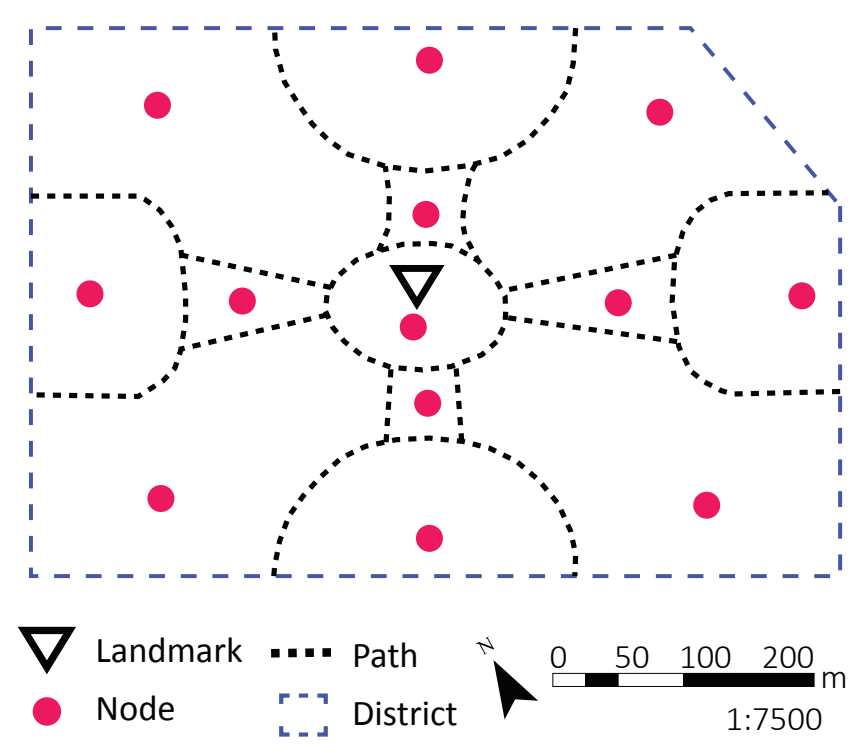
nodes, and landmarks is prominent in both developments. Due to the similarity of Lynch's description of edges and districts, this analysis will consider the term 'district' and will disregard the term 'edge'.

\section{Stuyvesant Town}

Paths: Stuyvesant Town has a network of paths that provide a clear pedestrian network between all parts of the development. The paths provide easy access to the residential buildings and parks. Central paths connect to a loop of circulation leading to each of the 4 main streets bounding Stuyvesant Town [Figure 9]. 
Districts: Stuyvesant Town can be considered 1 district. The homogenous shape and size of its built form, and the consistent placement of buildings around park space creates 1 uniform character.

Nodes: Stuyvesant Town's formal park and plaza spaces create distinct nodes within the complex.

Landmarks: One clear landmark within Stuyvesant Town is the central fountain within Stuyvesant Oval. This fountain creates a physical differentiation between its space and the rest of Stuyvesant Town, signalling its location within the central point of the housing complex.

Figure 10: Lynchian Analysis of Regent Park

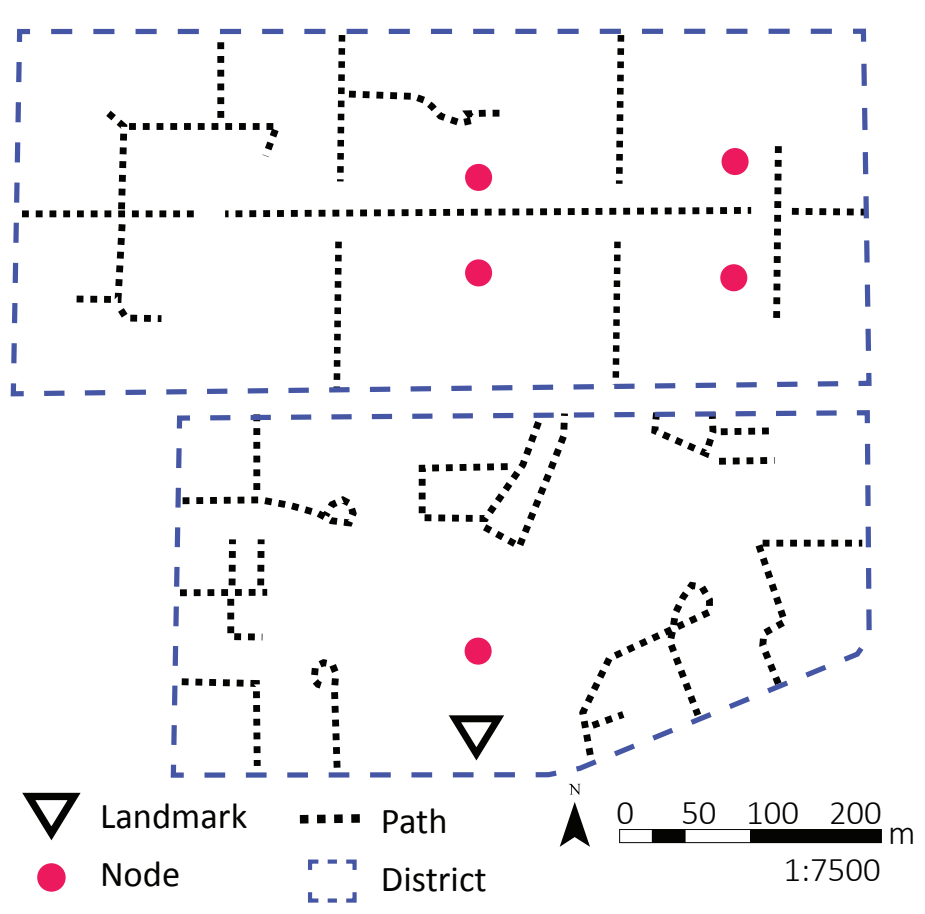

\section{Regent Park}

Paths: A Lynchian analysis of Regent Park highlights the lack of connectivity within the development. The majority of paths aid vehicular travel, with 1 formal pedestrian path extending east-west within the centre of Regent Park North. None of the paths create a consistent connection through the site [Figure 10].

Districts: The existence of Dundas Street creates 2 distinct districts: Regent Park North and Regent Park South. This is reinforced through circulation patterns (north-south and east-west in the North district, and inconsistent circulation routes within the South District), and the organization, shape, and density of each development's built form.

Nodes: Nodes exist in the form of parks, with the majority within Regent Park North.

Landmarks: None of Regent Park's residential buildings or park spaces act as formal landmarks. Park Public School in Regent Park South functions as a landmark due to its non-residential land use, emphasized by the large open park space to its north.

\section{Land Uses}

Neither Stuyvesant Town nor Regent Park employ a diversity of land uses as recommended by Jane Jacobs in The Death and Life of Great American Cities. Both developments employ predominantly 
residential land uses, with some parks and open space. The design of Regent Park includes more diversity in its land uses than Stuyvesant Town, featuring a few stores and institutional uses such as the public school, community centre, and churches in Regent Park South. Stuyvesant Town's design includes some commercial functions on its outer perimeter, facing the 4 main municipal streets bounding the development. Stuyvesant Town's lack of land use diversity was acknowledged in 2002 with the creation of a few stores and restaurants within the development (Bloom \& Lasner, 2015), such as the Stuyvesant Café and Stuyvesant Study.

\section{Key Takeaways}

Overall, there are many similarities in the urban design of Stuyvesant Town and Regent Park. However, Stuyvesant Town's design is more orderly than Regent Park, and provides more logical circulation. The organization of built form within Regent Park North is similar to Stuyvesant Town, whereas Regent Park South lacks consistent built form organization. However, both Regent Park North and South lack a consistent 'tower in the park' design, with only a few formal park spaces [Table 4]. 
Table 4: Urban Design of Stuyvesant Town and Regent Park

\begin{tabular}{|c|c|c|}
\hline & STUYVESANT TOWN & REGENT PARK \\
\hline Construction Period & 1943 to 1949 & 1948 to 1957 \\
\hline Urban Design Ideologies & Tower in the park model & Tower in the park model \\
\hline Master Plan Design & $\begin{array}{l}\text { Superblock plan, with no } \\
\text { through-streets }\end{array}$ & $\begin{array}{l}\text { Superblock plan, with no } \\
\text { through-streets }\end{array}$ \\
\hline Number of Developments & 1 development & $\begin{array}{l}2 \text { developments: North and } \\
\text { South }\end{array}$ \\
\hline Acreage & 72 acres & $\begin{array}{l}\text { Approximately } 69 \text { acres; } \\
\text { RPN: } 42.5 \text { acres; RPS: } 26.2 \text { acres }\end{array}$ \\
\hline $\begin{array}{l}\text { Approximate Population } \\
\text { Capacity }\end{array}$ & 24,000 & 10,000 \\
\hline Density & 334 people/acre & 145 people/acre \\
\hline Coverage & $25 \%$ & $\mathrm{~N} / \mathrm{A}$ \\
\hline Built Form Typologies & High-rise towers & $\begin{array}{l}\text { Low-rise row houses, mid-rise } \\
\text { buildings, and a few high-rise } \\
\text { towers }\end{array}$ \\
\hline Number of Residential Buildings & 35 & 62 total: RPN: 36; RPS: 26 \\
\hline Number of Units & 8,755 & $\begin{array}{l}\text { 2,021 total: } \\
\text { RPN: 1,289; RPS: } 732\end{array}$ \\
\hline Height of Buildings & 12 to 13 -storeys & $\begin{array}{l}\text { RPN: low-rise row house } \\
\text { buildings, and apartment } \\
\text { buildings of } 3 \text { and } 6 \text {-storeys } \\
\text { RPS: } 5,14 \text {-storey towers, and } \\
\text { low-rise row house buildings }\end{array}$ \\
\hline Shape of Buildings & Cross and L-shaped & Cross and L-shaped \\
\hline Arrangement of Buildings & $\begin{array}{l}\text { Symmetrical and ordered. } \\
\text { Organized around formal green } \\
\text { spaces and plazas. Internally } \\
\text { facing buildings create a 'wall' } \\
\text { around the site's perimeter }\end{array}$ & $\begin{array}{l}\text { RPN: Typically organized with } \\
\text { north-south or east-west } \\
\text { pattern, internally facing } \\
\text { RPS: Haphazard organization; } \\
\text { most internally facing }\end{array}$ \\
\hline Pedestrian Circulation & $\begin{array}{l}\text { Internal pedestrian path } \\
\text { network, providing access to } \\
\text { built form and parks }\end{array}$ & $\begin{array}{l}\text { Lack of pedestrian network; } \\
\text { central pathway in Regent Park } \\
\text { North }\end{array}$ \\
\hline Vehicular Circulation & $\begin{array}{l}8 \text { access points, with } 2 \text { on each } \\
\text { main street bounding Stuyvesant } \\
\text { Town }\end{array}$ & $\begin{array}{l}\text { Vehicular access restricted to } \\
\text { on-site parking around the } \\
\text { perimeter of the site }\end{array}$ \\
\hline Open Space & Formal parks and plazas & Formal parks \\
\hline Land Uses & $\begin{array}{l}\text { Predominantly residential, with } \\
\text { significant parks space, and a } \\
\text { few commercial uses }\end{array}$ & $\begin{array}{l}\text { Predominantly residential, with } \\
\text { limited parks space, commercial, } \\
\text { and institutional uses }\end{array}$ \\
\hline
\end{tabular}

Note: Abbreviations are as follows: Regent Park North (RPN) \& Regent Park South (RPS) 


\section{COMPARING THE LEGACIES OF STUYVESANT TOWN AND REGENT PARK}

\section{Policy Legacy}

Stuyvesant Town's success has been closely tied to its varying policy context and its relationship to the economics of affordable housing. The year 1974 ended the tax abatements on the Stuyvesant Town property negotiated by mayor La Guardia and Metropolitan Life in the 1940s. Rent stabilization legislation was used for Stuyvesant Town to maintain affordable housing (Glass et. al, 2014). J-51 tax abatements were introduced for Stuyvesant Town beginning in 1992, providing "as-of-right tax exemption and abatement for residential rehabilitation..." (City of New York, 2016a; Jones, 2010, Aug. 5). These abatements are still being used for Stuyvesant Town and will expire in 2020 (City of New York, 2015), and require rent stabilization (Garodnick, 2015). Shortly after Stuyvesant Town's creation, Metropolitan Life constructed Peter Cooper Village to the immediate north of Stuyvesant Town, which resulted in the eventual agglomeration of these 2 developments into Stuyvesant Town-Peter Cooper Village (Glass et. al, 2014; Goldfield, 2006).

In 2001, Metropolitan Life converted some of Stuyvesant Town's vacant apartments into market rate units, resulting in rents "ranging between \$2,100 and \$4,200 a month" (Goldfield, 2006, p. 774). This process did not affect any existing tenants living in Stuyvesant Town, allowing anyone living in the development prior to 1997 with rent stabilized apartments to continue to do so (Goldfield, 2006). In 2006, Met Life sold Stuyvesant Town to Tishman Speyer and Blackrock. However, the new owners "overestimated the pace of turnover and, in turn, their ability to decontrol rents and charge market rates" resulted in them paying an inflated price (Bloom \& Lasner, 2015, p. 154). The owners attempted to convert additional units to market rate, which was fought by existing residents (Bloom \& Lasner, 2015; Glass et. al, 2014). In 2010, Tishman Speyer defaulted on its loan for Stuyvesant Town, and relinquished control of the property to CW Capital who put it up for sale once again. In October 2015, Blackstone Group and Ivanhoé Cambridge bought Stuyvesant Town-Peter Cooper Village for a total of $\$ 5.3$ billion in a deal to keep 5,000 of its 11,200 apartments affordable for a minimum 20-year period (City of New York, 2015; Putzier, 2015, Oct. 29). The owners made a deal with the City to receive approximately $\$ 225$ million in benefits "through a loan and an uncollected tax" (Putzier, 2015, Oct. 29), in addition to the permission to sell some of Stuyvesant Town's air rights.

\section{Urban Design Legacy}

Whereas Stuyvesant Town's legacy is closely tied to changing planning policy, this is not the case for Regent Park. Unlike Stuyvesant Town, Regent Park has not been able to survive increasing economic hardships, nor varying social perceptions about the design of affordable housing. Only one decade after its completion, Regent Park became stigmatized as a 'slum' area, criticized for 
its poorly designed urban environment (James, 2010; Moskalyk, 2008; MTHA, 1962; Rose, 1968). Issues included a lack of open space, and high-rise buildings that created isolation within the development and from the surrounding City (James, 2010; MTHA, 1962). Regent Park's lack of through-streets was considered to further isolate the community from the City (Moskalyk, 2008). This was exacerbated by deteriorating buildings and high concentrations of poverty (James, 2010). Overall, Regent Park was criticized for "poorly planned public spaces" and insufficient "neighbourhood facilities" (James, 2010, p. 442). The urban design and built form of Regent Park's master plan has been deemed a colossal failure. Instead of creating a modernist utopian neighbourhood, Regent Park created an isolated enclave home to high levels of criminal activity (James, 2010). The area created to remedy Toronto's post-war urban housing problems "[was] once again condemned to the same socio-economic stigmatization, isolation and marginalization that [it] had experienced in the previous slums" (Carroll, 2012, p. 7). Regent Park's flawed design was one reason for the demolition of the original Regent Park, and its replacement with a mixeduse, mixed-income community. This 6-phase, \$1 billion project, with its estimated completion date of 2019, aims to integrate Regent Park into its surroundings and improve connectivity using public through-streets and a conventional street grid system (Contenta, 2007, May 19; Lorinc, 2013; Thomson \& Bucerius, 2012, June 16). The master plan will improve resident access to amenities with community services, public spaces, and commercial uses (Lorinc, 2013); many of these community facilities were funded through partnerships with governmental bodies such as the City of Toronto (TCHC, 2012). Built form will include townhouses, mid-rises and high-rises, with both social housing and market rate units (Lorinc, 2013). The creation of a public-private partnership between the Toronto Community Housing Corporation and The Daniels Corporation will result in 3000 market rate condominiums, which will fund the replacement of 2,083 new social housing units and 700 affordable rental units on-site (TCHC, 2012).

\section{The 'Myth' of Master Planning: More Than Urban Design}

\section{Changing Economic Circumstances}

The evolution of Stuyvesant Town and Regent Park has been greatly linked to the provision of affordable housing in a rapidly changing economy. The changing economic context for both Regent Park and Stuyvesant Town reflects the barriers to affordable housing provision faced by contemporary North American cities. Throughout the life of Stuyvesant Town, political influence has been used to make the development economically feasible through policy creation, which resulted in the funding and preservation of affordable housing. The ability to maintain affordable housing units within Stuyvesant Town, and the ability to replace all of Regent Park's social housing units was made possible only through partnerships between the private sector and municipal government. In the case of Stuyvesant Town, significant effort by the City was exerted in order to ensure the survival of many of Stuyvesant Town's affordable rental units. Similar to Stuyvesant Town, Regent Park was a victim to changing economic circumstances within its operating body. The 
Toronto Community Housing Corporation, Toronto's municipal social housing agent, continued to face economic strain, which impacted their ability to sufficiently maintain and operate their properties, including Regent Park (Côté \& Tam, 2013). Therefore, the creation of a public-private partnership was necessary to provide the required maintenance to the community, with the added benefit of addressing perceived urban design issues. These barriers to affordable housing reflect the lack of economic resources on the part of municipalities to provide affordable housing in the face of diminishing affordable housing stock, resulting in an increasing reliance on the private sector.

\section{Changing Social Perceptions}

The redevelopment of Regent Park and the changing ownership of Stuyvesant Town reflect changing social perceptions about the role of master planning. Contemporary master planning no longer promotes singular-zoned developments housing homogenous residents (Angotti \& Hanhardt, 2001; Talen, 2006), which has been considered a failure of North American city planning (Talen, 2006). Instead, professionals within the twenty-first century have promoted accessible, integrated, mixed-use communities, housing residents of diverse socio-economic backgrounds (Cooper, Evans, \& Boyko, 2009; Talen, 2006). The call for diversity in city planning by Jane Jacobs in the 1960s has become a foundation of the contemporary master plan (Angotti \& Hanhardt, 2001). This can be viewed as a reaction to the perceived elitism attached to the term 'master plan', changing from a vision of isolating enclaves to inclusive communities.

\section{Challenging the Myth}

Both Stuyvesant Town and Regent Park were designed using Le Corbusier's 'tower in the park' model, and the designs of both complexes feature many similarities. Though the majority of the blame for Regent Park's demise was attributed to its urban design, Stuyvesant Town has not received notable criticism on its design, nor has it been deemed an architectural failure. Saying that Regent Park's demise was the sole result of its urban design is similar to proclaiming that Pruitt-Igoe's demolition symbolized the 'death of modernism'; both statements are equally presumptuous and ignore the impact of relevant policies and social and economic contexts on these housing projects (Bristol, 1991). This is the 'myth' of master planning: master planning is not the result of urban design alone. Master planning is more than urban design, as it is shaped and reinforced by land use planning policy, which reflects changing social, economic, and political circumstances. Stuyvesant Town and Regent Park were as much a result of design ideologies as they were a result of the economic, social, and political contexts of their respective citiesreinforced through urban planning policies, urban housing policies, and urban planning studies. 


\section{CONCLUSION: THE COMPLEX NATURE OF MASTER PLANNING}

Master planning as a concept has historically been tied to urban design, without significant mention of urban planning policy, or social, economic, or political contexts. This paper argued that this preconceived notion of master planning is fundamentally flawed, deconstructing master planning through a case study analysis of the master-planned Stuyvesant Town and Regent Park. These case studies highlighted the multi-faceted nature of master planning through a comparative analysis of their process, policy, and urban design. Master planning needs to be understood as more than a function of urban design. Master plans are and should be considered a reflection of relevant urban planning policy, housing policy, and urban design ideologies, which are a reflection of social, economic, and political contexts. It is the hope that more research will be undertaken to further explore the relationship between master planning and urban design, urban planning, and urban housing policy, to build upon the research within this paper. Future research should include case study analyses of North American master-planned projects of varying sizes and landuse types. A comparison of contemporary residential and mixed-use projects may provide further insight into the role of urban design and land-use planning policy on master planning. 


\section{REFERENCES}

Angotti, T. \& Hanhardt, E. (2001). Problems and Prospects for Healthy Mixed-use Communities in New York City. Planning Practice \& Research, 16(2), 145-154. doi: 10.1080/02697450120077352

Bacon, M. (1984). Planning (?) in Ontario Prior to 1977. Plan Canada, 24(3/4), 115-117.

Blake, P. (1996). The Master Builders: Le Corbusier, Mies Van Der Rohe, Frank Lloyd Wright. New York: WW Norton.

Bloom, N., \& Lasner, M. (2015). Affordable Housing in New York: The People, Places, and Policies That Transformed a City. New Jersey: Princeton University Press.

(BLS) United States Bureau of Labor Statistics. (2016). CPI Inflation Calculator. Retrieved from http://www.bls.gov/data/inflation_calculator.htm

(BOC) Bank of Canada. (2016). Inflation Calculator. Retrieved from http://www.bankofcanada.ca/rates/related/inflation-calculator/

Bristol, K. (1991). The Pruitt-Igoe Myth. Journal of Architectural Education, 44(3), 163-171. Retrieved from http://www.jstor.org/stable/1425266

Bruce, H. (1934). Report of the Lieutenant-Governor's Committee on Housing Conditions in Toronto. Toronto: Committee to Enquire into Housing Conditions in the Several Areas of the City of Toronto.

Capeci Jr., D. (1978). Fiorello H. La Guardia and the Stuyvesant Town Controversy of 1943. The New York Historical Society Quarterly, 62(4), 289-310. Retrieved from http://chpcny.org/ wp-content/uploads/2010/07/History-of-Stuy-Town.pdf

Carroll, M. (2012). [Re]Forming Regent Park: From Policy to Practice, What's Lost in Translation? Retrieved from ProQuest Digital Dissertations. (UMI 1514352).

Carver, H. (1946). Memorandum on the Regent Park Housing Project. Toronto: Toronto Reconstruction Council.

Ching, F., Jarzombek, M., \& Prakash, V. (2011). A Global History of Architecture, second ed. New Jersey: John Wiley \& Sons, Inc.

City of New York. (2016a). Tax Incentives: J-51. Retrieved from http://www1.nyc.gov/site/hpd/developers/tax-incentives-j51.page 
City of New York. (2016b). Zoning Background. Retrieved from http://www1.nyc.gov/site/planning/zoning/background.page

City of New York. (2015). Mayor, Local Elected Officials and Tenant Leaders Announce 20-Year Agreement with Blackstone and Ivanhoé Cambridge to Protect Middle Class Housing at Stuyvesant Town and Peter Cooper Village. Retrieved from http://www1.nyc.gov/ office-of-the-mayor/news/736-15/mayor-local-elected-officials-tenant-leaders-20-yearagreement-blackstone-and\#/0

City of Toronto Archives. (2016). District, Regent Park and Moss Park: Aerial Photograph of Regent Park looking East [Image]. Retrieved from http://libguides.gwumc.edu/c. php?g=27779\&p=170351

(Committee on Housing) Committee on Housing and Urban Development. (1945). Multiple Dwelling Law, a Clarification. Retrieved from http://hdl.handle.net/2027/uc1.b3116906

Contenta, S. (2007, May 19). A Loss Close to the Heart. Toronto Star. Retrieved from http://www.thestar.com/news/2007/05/19/a_loss_close_to_the_heart.html

Cooper, R., Evans, G., \& Boyko, C. (ed.). Designing Sustainable Cities. West Sussex: WileyBlackwell.

Côté, A. \& Tam, H. (2013). Affordable Housing in Ontario: Mobilizing Private Capital in an Era of Public Constraint. IMFG Perspectives, 3, 1-10. Retrieved from http://munkschool. utoronto.ca/imfg/uploads/238/1409affordablehousingproofr2.pdf

(CPB) City Planning Board (Toronto). (1943). Master Plan for the City of Toronto and Environs. Toronto: City Planning Board.

Curtis, W. (2009). Modern Architecture Since 1900, third ed. New York: Phaidon Press Limited.

Firley, E. \& Grön, K. (2013). The Urban Masterplanning Handbook. West Sussex: John Wiley \& Sons Ltd.

Ford, J. (1971). Slums and Housing: With Special Reference to New York City: History, Conditions, Policy. Westport: Negro Universities Press.

Garodnick, D. (2015). Frequently Asked Questions: Stuyvesant Town and Peter Cooper Village Sale to Blackstone. Retrieved from http://www.garodnick.com/press-release/frequentlyasked-questions-stuyvesant-town-and-peter-cooper-village-sale-blackstone

George, R. (2010). The Bruce Report and Social Welfare Leadership in the Politics of Toronto's "Slums", 1934-1939. Social History, 44(87), 83-114. doi: 10.1353/his.2011.0010 
Glass, M., Woldoff, R., \& Morrison, L. (2014). Does The Middle Class Have Rights to The City? Contingent Rights and The Struggle to Inhabit Stuyvesant Town, New York. International Journal of Housing Policy, 14(3), 214-235. doi:10.1080/14616718.2014.931717

Goldfield, D. (ed.). (2006). Encyclopedia of American Urban History. California: SAGE Publications.

Hall, Peter. (2014). Cities of Tomorrow: An Intellectual History of Urban Planning and Design Since 1880, fourth ed. West Sussex: Wiley Blackwell.

(HAT) The Housing Authority of Toronto. (1951). Regent Park (North) Housing Project: Canada's Premier Housing Redevelopment Project. Toronto.

(HHFA) United States Housing and Home Finance Agency (1950). A Handbook of Information On Provisions of the Housing Act of 1949 and Operations Under the Various Programs. Retrieved from http://hdl.handle.net/2027/mdp.39015024351168

(ICE) Institute of Civil Engineers. (2010). A New Urbanity: The Relationship Between Towers and Urbanism. Civil Engineering 163, Paper 10-00002, 4-11. doi: 10.1680/cien.2010.163.6.4

(ICZ) Independent Committee on Zoning. (1942). Draft Zoning By-Law. City of Toronto.

Jacobs, J. (1961). The Death and Life of Great American Cities. New York: Vintage Books.

James, R. (2010). From 'Slum Clearance' to 'Revitalization': Planning, Expertise and Moral Regulation in Toronto's Regent Park. Planning Perspectives, 25(1), 69-86. doi: $10.1080 / 02665430903421742$

Jones, David. (2010, Aug. 5). Ruling Says Metlife Could Face Claims for Stuy Town Rent Overcharges. The Real Deal Real Estate News. Retrieved from http://therealdeal. com/2010/08/05/ruling-says-metlife-could-face-claims-for-stuy-town-rent-overcharges/

Lorinc, J. (2013). The New Regent Park. U of T Magazine. Retrieved from http://magazine.utoronto.ca/feature/new-regent-park-toronto-community-housingjohn-lorinc/

Lynch, K. (1960). The Image of the City. Cambridge: MIT Press.

Moskalyk, A. (2008). The Role of Public-Private Partnerships in Funding Social Housing in Canada. Canadian Policy Research Networks. Retrieved from http://rcrpp.org/ documents/50550_EN.pdf

(MTHA) The Metro Toronto Housing Authority. (1962). South Regent Park: A Study. Toronto. 
Plunz, R. (1990). A History of Housing in New York City: Dwelling Type and Social Change in the American Metropolis. New York: Columbia University Press.

Putzier, K. (2015, Oct. 29). How Stuy Town Was Won. The Real Deal Real Estate News. Retrieved from http://therealdeal.com/2015/10/29/how-stuy-town-was-won/

Riis, J. (1890). How the Other Half Lives: Studies Among the Tenements of New York. Retrieved from https://ryerson.summon.serialssolutions.com/\#!/search?bookMark=ePnHCXMw42JgAfZ bUzkZJDzyyxWAjRgF8E4ihYzEnDSFHNBRqtwMCm6ulc4eutBGZTx0oClCdgZAfZGLEAXFRNUAgB-Eh_I

Rose, A. (1958). Regent Park: A Study in Slum Clearance. Toronto: University of Toronto Press.

Schwartz, J. (1993). The New York Approach: Robert Moses, Urban Liberals, and Redevelopment of the Inner City. Columbus: Ohio State University Press.

Solomon, L. (2007). Toronto Sprawls: A History. Toronto: University of Toronto Press.

Stein, R. (2001). London's Londons: Photographing Poverty in The People of the Abyss. Nineteenth-Century Contexts, 22, 587-629. doi: 10.1080/08905490108583527

Stern, R., Mellins, T., \& Fishman, D. (1995). New York 1960: Architecture and Urbanism Between the Second World War and the Bicentennial. New York: The Monacelli Press.

Talen, E. (2006). Design for Diversity: Evaluating the Context of Socially Mixed Neighbourhoods. Journal of Urban Design, 11(1), 1-32. doi: 10.1080/13574800500490588

Taylor, N. (2009). Legibility and Aesthetics in Urban Design. Journal of Urban Design, 14(2), 189202, doi: $10.1080 / 13574800802670929$

(TCHC) Toronto Community Housing Corporation. (2012). Regent Park Revitalization. Retrieved from http://www.torontohousing.ca/news/20120327/regent_park_revitalization

(TDD) Toronto Development Department: Research \& Information Division. (1972). Regent Park North. Toronto.

(TDD) Toronto Development Department: Research \& Information Division. (1971). Regent Park South. Toronto.

(THA) Toronto Housing Authority. (1950). Regent Park (North) Housing Project. Toronto. 
Thomson, S., \& Bucerius, S. (2012, June 16). Regent Park Revitalization: Has It Created an "Us versus Them" Dynamic? Toronto Star. Retrieved from http://www.thestar.com/news/ gta/2012/06/16/regent_park_revitalization_has_it_created_an_us_versus_them_ dynamic.html

(USHA) United States Housing Authority. (1937). The United States Housing Act of 1937 as Amended and Provisions of Other Laws and of Executive Orders Pertaining to the United States Housing Act of 1937, as Amended. Retrieved from http://hdl.handle.net/2027/ uc1.b3866883

White, R. (2007). The Growth Plan for the Greater Golden Horseshoe in Historical Perspective. Neptis Foundation, Paper 4. Retrieved from http://www.neptis.org/sites/default/files/ historical_commentary/historicalcomm_web_200711291.pdf

(Yale) Yale Law Journal Company, Inc. (1944). Urban Redevelopment. The Yale Law Journal, 54(1), 116-140. Retrieved from http://www.jstor.org/stable/792719

Zipp, S. Manhattan Projects. (2010). New York: Oxford University Press.

Zipp, S. (2006, Sept. 3). A Landmark's Middle-Class Myth. New York Times. Retrieved from http://www.nytimes.com/2006/09/03/opinion/nyregionopinions/03Clzipp.html?_r=0 